\title{
Utilization of Agricultural Waste for the Production of Xylooligosaccharides Using Response Surface Methodology and Their In Vitro Prebiotic Efficacy
}

Nagamani Kathiresan ( $\sim$ mailtonaga007@gmail.com )

The Gandhigram Rural Institute Deemed University https://orcid.org/0000-0001-9676-9444

Lingesh Gopal

The Gandhigram Rural Institute Deemed University

Vijay Karuppiah

Alagappa University

Renuka Naveenethan

The Gandhigram Rural Institute Deemed University

David Ravindran Abraham

The Gandhigram Rural Institute Deemed University

Kavitha Thangavel

Alagappa University

\section{Research Article}

Keywords: Xylooligosaccharide, Xylan, Sugarcane bagasse, prebiotic, probiotic, Fermented foods, bacteriocin

Posted Date: September 14th, 2021

DOI: https://doi.org/10.21203/rs.3.rs-748907/v2

License: (9) This work is licensed under a Creative Commons Attribution 4.0 International License.

Read Full License 
2

3

6 7

8

$9 *$ Corresponding author

10 Dr.A.David Ravindran M.Sc., PhD,

11 Professor (Retd),

12 The Gandhigram Rural Insitute- Deemed to be University,

13 Gandhigram 624302, Dindigul, Tamil Nadu, India,

14 david_gri@rediffmail.com, 9245171248

15 ORCiDs

16 Author 1: https://orcid.org/0000-0001-9676-9444

17

18

19

20

21

22

23

24

25

26

27 and Kavitha Thangavel ${ }^{2}$ 624302, Tamil Nadu, India.

Author 3: $\underline{\text { https://orcid.org/0000-0001-7950-7899 }}$

Author 6: $\underline{\text { https://orcid.org/0000-0002-7554-3080 }}$

\section{IN VITRO PREBIOTIC EFFICACY}

Nagamani Kathiresan ${ }^{1}$, Lingesh Gopal ${ }^{1}$, Vijay Karuppiah ${ }^{2}$, Renuka Naveenethan ${ }^{1}$, David Ravindran Abraham $^{1 *}$

${ }^{1}$ Department of Biology, The Gandhigram Rural Institute Deemed to be university, Gandhigram, Dindigul

${ }^{2}$ Department of Microbiology, Molecular biology lab, Alagappa University, Karaikudi, Tamil Nadu, India. 
34 Graphical abstract
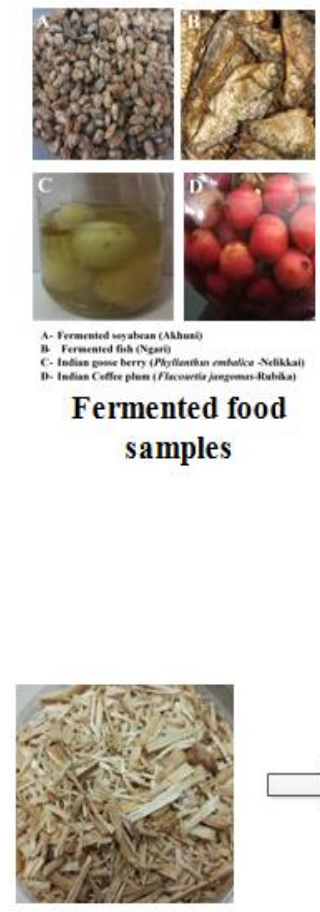

Sugarcane bagasse

\section{Isolation and \\ Identification}

Lactobacillus plantarum MT228948,

Lactobacillus fermentum MT230901, Bacillus amyloliquefaciens MT193292,

Bacillus clausii 658363 and

Bacillus faecium MN956828

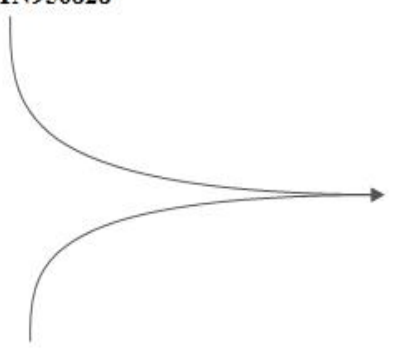

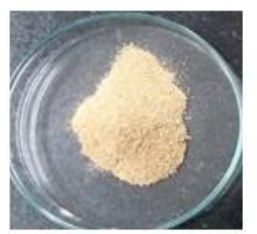

Alkali

extracted

Xylan

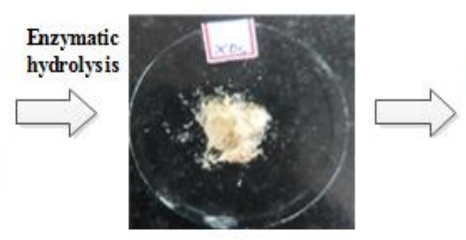

xos
BLIS production against human pathogen

Selection based on probiotic criteria's

Characterization of XOS by FTIR, NMR, XRD, TGA, LC-MS

- in vitro prebiotic potential 


\section{Abstract}

43 Air pollution is a prominent problem recently faced in various parts of India due to the burning of stubbles 44 (coconut husk, corn cob, paddy stubbles, sugarcane bagasse, etc.) which are rich in a lignocellulosic component that can be converted into a prebiotic known as Xylooliogsaccaride (XOS). They can be produced by autohydrolysis, acid hydrolysis and enzymatic hydrolysis of xylan. In the present study, Xylan was extracted from sugarcane bagasse using two alkalis $(\mathrm{NaOH}$ and $\mathrm{KOH})$ and the yield was compared. Xylooligosaccharide produced by enzymatic hydrolysis and their factors influencing the yield were optimized using Response Surface Methodology. Xylan and Xylooligosaccharide was characterized by FTIR, NMR, XRD, TGA and ESI-MS. Xylooligosaccharides was investigated for their prebiotic potential by in vitro study. The maximum (Relative yield of $86 \%$ ) yield of xylan was observed in $20 \%$ of $\mathrm{NaOH}$. Xylan peaks at $3762 \mathrm{~cm}^{-1}, 3347 \mathrm{~cm}^{-1}, 2917 \mathrm{~cm}^{-1}$ represents the $\mathrm{OH}$ and $\mathrm{CH}$ stretching of xylan. The main signals at $4.26(\mathrm{H}-1), 3.19(\mathrm{H}-2), 3.59(\mathrm{H}-3), 3.63(\mathrm{H}-$ 4) and 3.98 (H-5) ppm determines the existence of xylan. The higher amount of XOS is pH 4.75, temperature $45^{\circ} \mathrm{C}$, enzyme $4 \mathrm{U} / \mathrm{ml}$ and for time of $16 \mathrm{~h}$. The spectrum of $5.0-5.40 \mathrm{ppm}$ and $4.30-4.60 \mathrm{ppm}$ represents the $\alpha$ anomeric and $\beta$ anomeric protons in XOS. They are resistant digested and the reaching percentage to the intestine is 95\% unhydrolyzed. The maximum prebiotic index was noted in L.plantarum (1.92) and L.fermentum (1.61). The highest prebiotic index and score was observed in L.plantarum (1.9) and L.fermentum (17). The maximum bacteriocin production of Enterococcus faecium against E.fecalis $(13 \mathrm{~mm})$ and Streptococcus pyogenes $(11 \mathrm{~mm})$. Therefore, utilization of agricultural residues for a value-added product not only shows a great impact on environmental issues but also could double the farmer's income 
75 Sugarcane (Saccharum officinarum L.) is a perennial crop that grows predominantly in subtropical and tropical regions. Sugarcane bagasse (SB) is a fibrous residue of cane stalk left after the crushing and extraction of juices. Sugarcane bagasse is one of the most abundant lignocellulosic materials in the agro-industrial residues (Cardona et al. 2010) consisting of cellulose, hemicellulose and lignin. A total of $54 \times 10^{8}$ dry tons of sugarcane is processed annually around the world and 1 ton of sugarcane generates $280 \mathrm{kgs}$ of bagasse (Cerqueira et al. 2007). About $50 \%$ of these residues are used for generating power and heat to run the sugar, ethanol and distillery plants. The remaining bagasse are piled up which may cause spontaneous combustion of stored bagasse (Lavarack et al. 2000 and Pandey et al. 2000). Xylooligosaccharides (XOS) are the prebiotic component obtained from the plant biomass. Biomass of plant origin is one of the renewable and cheapest raw materials for sustainable development. That could be a promising initiator for the production of biofuel and bioenergy along with value-added biomolecule (Prebiotic). Prebiotics, as the name, implies "Pre- before; bio-life" it is evolved before life evolved. But it came to light in 1995 with the definition given by Gibson and Roberfroid (1995) as "Nondigestible food ingredients that beneficially affect the host by selectively stimulating the growth and or activity of one of the limited number of bacteria in the colon" (Samanta et al. 2014).

XOS is the synthesized prebiotics from various agricultural residues viz., corncob sugarcane bagasse, stalks of cotton, tobacco and shells of pistachios, walnut and groundnut, etc., they are hydrolyzed products of xylan a polysaccharide which is synthesized by various methods. These agricultural wastes are dumped in the field or burned after harvesting (Agrupis and Markawa 1999). By utilizing these wastes will protect the environment from pollution as well as increases the economic status of farmers and generates employment (Akpinar et al. 2009).

94 From a nutritional point of view, XOS is known as nondigestable (ND) as they are not degraded in the stomach and reaches the lower bowel, to be utilized by the microbiota residing there (Okazaki et al. 1990; Roberfroid 1999; Collins and Gibson 1999; Vazquez et al.2000). They have also helped in reducing cholesterol and maintains gut health. They are moderately sweet, inhibit the retrogradation of starch, and improves the sensory and nutritional properties of food and are stable for a wide range of $\mathrm{pH}$ and temperature (Vorgen 1998). XOS is noncarcinogenic and regulates insulin secretion from the pancreas, besides increasing mineral absorption from the large intestine.

100 It affects bowel function through its mild laxative ability. The prebiotic consumption gradually raises the ability to stimulate the growth of indigenous Bifidobacterium and Lactobacillus in the hindgut which in turn suppress

102 the growth and activity of harmful or putrefactive bacteria and reduces the concentration of toxic substances in

103 the gastrointestinal tract (Samanta et al. 2007, 2010). XOS predominantly increases the population of

104 Bifidobacterium and Lactobacillus which results in the production of SCFA by the prebiotic fermentation which 105 helps in important physical events viz., Calcium absorption, bowel function, lipid metabolism and reduces the risk 106 of colon cancer (Rycroft et al. 2001).

107 The Prebiotic potential is attributed by the utilization and nourishment of probiotic via fermentation thrive to 108 maintain the gut microflora diversity by eliminating the harmful pathogen (Gibson et al. 2004). The prebiotic 109 index and score can be calculated by comparing the stimulated growth by prebiotic on beneficial microbial 110 diversity and other intestinal pathogens (Huebner et al. 2007). 
111 Bacteriocins can be defined as extracellularly released peptides or protein molecules which have low molecular

112 weight with a bacteriostatic mode of action of closely related species. Bacteriocins are classified into three classes

113 based on their structure and function (Klaenhammer 1993). The action or effectiveness of the probiotics depends

114 mainly on the type of strain and the amount consumed. Prevention of growth of the pathogenic organisms by

115 occupying all the adhesion sites as pathogenic organisms also need to adhere and attach to the epithelial cells of

116 the intestine. The action might also be due to the synthesis of the acids and generating the acidic environment and

117 prevents the growth of pathogens. The immunological benefits conferred by probiotics are by prevention of

118 allergies due to activation of macrophages and thereby increasing antigen presentation and increases secretion of 119 immunoglobulin A.

120 In this research, the xylan was extracted from the sugarcane bagasse by alkali extraction and xylooligosaccharides 121 has been produced by enzymatic hydrolysis and studied for its in vitro prebiotic potential and their bacteriocin 122 activity against pathogens

\section{Materials and methods}

\subsection{Strains used}

The probiotic organisms were isolated from fermented foods viz., fish (Ngari), soyabean (Akhuni), Indian goose

126 berry and Indian coffee plum, identified and submitted in NCBI were used in this study viz., Lactobacillus 127 plantarum MT228948, Lactobacillus fermentum MT230901, Bacillus amyloliquefaciens MT193292, Bacillus 128 clausii 658363 and Bacillus faecium MN956828.

\subsection{Sample collection and processing of the sample}

130 Sugarcane bagasse was collected from the local Chinnalapatti market, Dindigul district, Tamil Nadu. The 131 collected Sugarcane Bagasse was washed with hot water to remove the dirt and dried in a hot air oven at $60 \pm 2{ }^{\circ} \mathrm{C}$. 132 The dried sample was powdered with a mechanical blender and stored in an airtight container until further usage.

\subsection{Compositional analysis of Sugarcane bagasse}

134 The composition of sugarcane bagasse (Cellulose, Hemicellulose and Lignin) was analyzed gravimetrically 135 (Ayeni 2015). The physicochemical parameters Moisture analysis (ASTM D2216 1993), Ash content (ASTM 136 D2866, 2000) and Lipid content (Soxhlet method) of sugarcane bagasse were quantified. All estimations were 137 carried out in triplicates.

\section{$138 \quad 2.4$ Extraction of xylan by alkali (KOH and $\mathrm{NaOH})$ treatment.}

139 Xylan was extracted from sugarcane bagasse by alkali treatment coupled with steam treatment according to 140 Samanta et al. (2012) with slight modification. The sugarcane bagasse was treated with alkaline viz., KOH and $141 \mathrm{NaOH}$ in a series of concentrations from $4 \%$ to $40 \%$. Sugarcane bagasse was soaked overnight in alkali with a 142 solid to liquid ratio of (10: 1) and they are autoclaved for $20 \mathrm{~min}$ at $121^{\circ} \mathrm{C}$. The solid-liquid fractions were 143 centrifuged at $\mathrm{x} 10000 \mathrm{rpm}$ for $15 \mathrm{~min}$. The supernatant was neutralized to pH6 using $1 \mathrm{~N}$ glacial acetic acid and 2 144 volumes of ice-cold ethanol (70\%) were added and allowed for precipitation. The aliquots were centrifuged at $145 \mathrm{x} 10000 \mathrm{rpm}$ for $20 \mathrm{~min}$ and the pellets were washed twice with distilled water, lyophilized, homogenized and 146 stored at $20^{\circ} \mathrm{C}$ until further usage. The maximum recovery of xylan from the sample (True yield) and 147 hemicellulose (Relative yield) can be calculated using the following formulae (Jnawali et al. 2018) 
152 Design (CCD). The extracted sugarcane bagasse xylan was subjected to enzymatic hydrolysis using commercial xylanase enzyme extracted from $T$. viridae (Sigma, Bangalore). The experiments were carried out in triplicates with 29 runs by varying $\mathrm{pH}$ ( 4 to 5.5 ), temperature $\left(40^{\circ} \mathrm{C}\right.$ to $55^{\circ} \mathrm{C}$ ), enzyme ( $4 \mathrm{U}$ to $20 \mathrm{U}$ ) and incubation time (8 to 24 hours). Two percent of substrates were added to $10 \mathrm{ml}$ of sodium citrate buffer and $1 \mathrm{ml}$ of enzyme and incubated in shaking waterbath at $\mathrm{x} 150 \mathrm{~g}$ for appropriate temperature and time. The aliquots were drawn from the enzymatic hydrolysis and the mixture was heated to $100^{\circ} \mathrm{C}$ to inactivate the enzyme and the hydrolysate was filtered with Whatman No1 filter paper. Three volumes of ice-cold ethanol were added to the filtrate to precipitate the traces of unhydrolyzed xylan (Samanta et al. 2014) and it was vacuum filtered using G3 sintered crucible filter and the filtrate was analyzed for its non-reducing sugar (XOS) by Lane and Eyon chemical method The optimization study was designed using by Design expert software version 11 .

\subsection{Detection and purification of Xylooligosaccharides}

163 The crude xylooligosaccharide was purified by the Activated charcoal column chromatography method according

164 to Chapla et al. (2012) with slight modification. Briefly, the activated charcoal was added to the crude XOS with a solid to liquid ratio of $1: 10$ and they were incubated at $25^{\circ} \mathrm{C}$ for $30 \mathrm{~min}$ at $150 \mathrm{rpm}$ in a cooling shaking incubator.

166 After incubation, the charcoal mixture was washed with 5 volumes of distilled water by vacuum filtration, as the monosaccharides in the mixture solution get washed off and the XOS adheres to the pores of activated charcoal. The charcoal containing XOS mixture is packed into the column with bed volume $1-2 \mathrm{~cm}$ length with $2.3 \mathrm{~cm}$ width as the stationary phase and $90 \%$ ethanol was used as the eluent. Elution was carried out at room temperature with gravitational force at a flow rate of $5 \mathrm{ml} /$ hour. 6 fractions of $5 \mathrm{ml}$ each were collected and Thin Layer Chromatography (TLC) was performed. The desired fractions were pooled together and concentrated using a Rotary Vacuum evaporator and lyophilized and stored at $4^{\circ} \mathrm{C}$ until further use.

\subsection{Characterization of Xylan and Xylooligosaccharides}

\subsubsection{Fourier Transform Infra-Red (FTIR) analysis}

175 Surface functional groups of Xylan and Xylooligosaccharides extracted from Sugarcane bagasse were unraveled 176 by FTIR (Perkin-Elmer infrared spectrophotometer, India). The xylan and Xylooligosaccharides were mixed with $177 \mathrm{KBr}$ (spectroscopic grade) separately and pellets were prepared in the size of about 10-30 mm diameter and $1 \mathrm{~mm}$ 178 in thickness (Jayapal et al. 2013). The samples were scanned in transmission mode with a resolution of $4 \mathrm{~cm}^{-1}$ in 179 the 4000-400 $\mathrm{cm}^{-1}$ range and the functional groups were compared with previously published works of literature.

\subsubsection{X-ray Powder Diffractions for Xylan and XOS}

181 To determine the physical nature of Xylan and Xylooligosaccharides, X-ray diffraction (XRD) was analyzed using 182 a powder diffractometer (PANalytical/XPert 3, New York). The structural property of Xylan and 
183 Xylooligosaccharides was identified using Bragg's law by measuring the line spacing in diffraction pattern (d)

184 and angle of incidence $(\theta)$ where $\lambda$ is the wavelength of the monochromatic X-ray beam.

$$
\mathbf{d}=\frac{\lambda}{\mathrm{n} \sin \theta}
$$

The crystallinity index (CI) of Xylan and Xylooligosaccharides was also evaluated by calculating the ratio of area under the crystalline peaks and total area of the scattered diffractogram using followed formulae (Singh et al.

187 2011).

$$
C I=\frac{\varepsilon \mathbf{A}_{\text {Crystal }}}{\varepsilon \mathbf{A}_{\text {Crystal }}+\varepsilon \mathbf{A}_{\text {amorphous }}}
$$

\subsubsection{NMR analysis for XOS} Approximately 10mg of xylan and Xylooligosaccharides samples were dispersed in Dimethyl Sulfoxide (DMSO) and Deionized water (Peng et al. 2010) and these solutions were used to record the ${ }^{1} \mathrm{H}$ and ${ }^{13} \mathrm{C}$ spectra. The Acquired time (AQ) is 4.089 seconds. The number of scans was 16 (NS) and the delay between transients was 2 seconds. Data were processed using the Bruker Topsin NMR software (Bruker, Avance III HD Nanobay 400 MHz FT-NMR SPECTROMETER, California)

\subsubsection{Thermogravimetric Analysis (TGA)}

197 The thermal stability of the xylan and Xylooligosaccharides component was determined by Thermogravimetric

198 analysis ( NETZSCH, NJA - STA 2500 Regulus, Germany) (Bian et al. 2010). $10 \mathrm{mg}$ of dried xylan and

199 Xylooligosaccharides samples were dried in a desiccator before experimenting. $2 \mathrm{mg}$ of samples were loaded in

200 the crucible and heated up to $600^{\circ} \mathrm{C}$ from room temperature at a rate of $10^{\circ} \mathrm{C} / \mathrm{min}$ with a continuous flow of 201 nitrogen.

\subsubsection{Liquid Chromatography-Mass Spectroscopy (LC-MS)}

203 The macromolecules in the sample were analyzed by 6530Q-TOF LCMS (Agilent, United States). $2 \mu 1$ of XOS 204 sample diluted in methanol was injected into the column and ionized by electron spray ionization source in a 205 positive ion charge mode. The scan was performed for the mass charge range $(\mathrm{m} / \mathrm{z})$ between 100-1000 206 (Xiao et al. 2018).

\subsection{Prebiotic attributes}

\subsubsection{Resistance to acid hydrolysis}

209 The resistance to gastrointestinal tract fluids was studied according to Wang (2009) and Winchienchot et al. 210 (2010). Artificial human gastric juice was mimicked by using hydrochloric acid buffer containing (in g/L) NaCl, $2118 ; \mathrm{KCL}, 0.2 ; \mathrm{Na}_{2} \mathrm{HPO}_{4} .2 \mathrm{H}_{2} \mathrm{O}, 8.25 ; \mathrm{NaHPO}_{4}, 14.35 ; \mathrm{CaCl}_{2} .2 \mathrm{H}_{2} \mathrm{O}, 0.1 ; \mathrm{MgCl}_{2} .6 \mathrm{H}_{2} \mathrm{O}, 0.18$. This buffer was adjusted 212 to $\mathrm{pH} 1$ to $5 \mathrm{using} 5 \mathrm{M} \mathrm{HCl}$. This buffer $(5 \mathrm{ml}$ at each $\mathrm{pH})$ was added to the sample solution $(1 \% \mathrm{w} / \mathrm{v}, 5 \mathrm{ml})$ and 213 incubated in a water bath $\left(37 \pm 1^{\circ} \mathrm{C}\right)$ for 6 hours. Sample $(1 \mathrm{ml})$ was taken periodically at $0,0.5,1,2,4$ and 6 hours 214 and tested for reducing sugar content using the dinitrosalicylic acid (DNS) and also total sugar content using the 215 Anthrone method. In this experiment, Inulin was used as a control. Percentage of the sample was calculated based 216 on reducing sugar released and total sugar content of the sample as below: 


\subsubsection{Prebiotic efficiency}

219 The capability of probiotics to utilize prebiotics for their growth as a carbon source was determined according to

220 Agte et al. (2010) protocol with slight modification. Probiotic cultures Lactobacillus sp. and Bacillus sp. were grown in their specific medium viz., Lactobacillus- MRS broth and Bacillus-Nutrient broth by altering the carbon source of the synthetic medium with XOS and EPS each. The utilization of prebiotics was analyzed by the growth of probiotic cultures using the visible spectrophotometer at $600 \mathrm{~nm}$ every 12 hours after incubation for a day.

\subsubsection{Prebiotic Index}

The prebiotic index is a growth comparison of probiotic on control media and prebiotic substituted media was analyzed according to Rodriguez et al. (2019). Probiotics were inoculated into the sterilized control media and carbon sources substituted with prebiotic and incubated at $37 \pm 2^{\circ} \mathrm{C}$ for 24 hours and it was calculated using the following formula by reading the growth at $600 \mathrm{~nm}$

$$
\text { Prebiotic Index }=\frac{A_{600 \mathrm{~nm}} \text { of probiotic growth in prebiotic subtituted medium }}{A_{600 \mathrm{~nm}} \text { of probiotic growth in control medium }}
$$

\subsubsection{Prebiotic activity score}

The utilization of prebiotics by probiotic cultures and an indicator $E$. coli were determined following the protocol of Huebner et al. (2007) by comparing their growth at $0^{\text {th }}$ and 24 hours of incubation using UV- Visible spectrophotometer at $600 \mathrm{~nm}$. The cultures grown in media without prebiotics were used as control. The prebiotic score was calculated using the following formula:

Prebiotic activity score

probiotic growth at 24th hrs with Prebiotics - Probiotic growth at 0th hr with Prebiotics

\subsection{Bacteriocin production from probiotic with prebiotic}

The probiotic cultures grown in prebiotics substituted medium were screened for its bacteriocin activity using the agar well diffusion method. Briefly, the isolates were inoculated in $50 \mathrm{ml}$ of respective prebiotic substituted medium and incubated overnight at $37^{\circ} \mathrm{C}$ for 24 hours. The isolates were centrifuged in the cooling centrifuge at $4^{\circ} \mathrm{C}$ at the rate of $x 5000 \mathrm{~g}$ for 20 minutes. The supernatant was filtered through a $0.22 \mu \mathrm{m}$ membrane filter to remove the bacterial cell to obtain Cell-Free Supernatant (CFS) and adjust to $\mathrm{pH}$ 6. The pathogens were swabbed onto the nutrient agar plate and $6 \mathrm{~mm}$ diameter wells were cut using a sterile well diffuser. Consequently, 100 $\mu \mathrm{l}$ presence of zone, measured zone using zone scale. 


\section{Results and Discussion}

\subsection{Compositional Analysis of Sugarcane bagasse}

Agricultural residues being dumped dumped or burned in fields, both activities lead to environmental problems; hence these residues can be potentially converted into a value-added prebiotic component Xylooligosaccharide. The Plant biomass are mainly composed of cellulose, hemicellulose and lignin components. In this research, the composition of sugarcane bagasse was analyzed and composed of cellulose (36 $\pm 0.02 \%)$; hemicellulose $(25 \pm 0.03 \%)$, lignin $(20.23 \pm 0.04 \%)$, Ash content $(1.23 \pm 0.15 \%)$ and wax less than 1 (Fig. 1). Similarly analysis of sugarcane bagasse had been carried out by Ayeni et al. (2015) and Bon and Ferrara (2007).

\subsection{Alkali extraction of xylan from sugarcane bagasse}

Treating lignocellulose-rich agricultural residues to alkali results in swelling of cellulose and rupturing of cell walls and high temperature softens the protective shielding lignin layer (Lavarack et al. 2002). Extraction of xylan with alkali like $\mathrm{NaOH}$ and $\mathrm{KOH}$ does not require any special instrument and it is an affordable and simple method. The xylan has been steadily increased when incrementing of concentration up to $20 \%$ of $\mathrm{NaOH}$ or $\mathrm{KOH}$ giving a true yield of $22 \%$ and $20 \%$ and relative yield of $86 \%$ and $78 \%$. By comparing the xylan yield among the alkali used, the maximum xylan yield was observed in $20 \% \mathrm{NaOH}$ combined with steam-treated sugarcane bagasse (Table 1). Jayapal et al. 2013 have compared the xylan extraction with two different alkali. The relative recovery for $\mathrm{KOH}$ is 6 to $53 \%$ and 12 to $85 \%$ for $\mathrm{NaOH}$. Samanta et al., 2012 also compared the alkali extraction of xylan from natural grass (Sehima nervosum) and the true yield of $\mathrm{KOH}$ is $2.47 \%$ to $16.52 \%$ and $\mathrm{NaOH}$ is 3.75 to $25.12 \%$ and the maximum relative yield for $\mathrm{KOH}$ is $23.43 \%$ and $83.38 \%$ for $\mathrm{NaOH}$.

\subsection{Optimization and Production of XOS from xylan using Response Surface Model (RSM).} RSM quadratic model was adopted to maximize the yield of XOS production and minimize the undesirable product (xylose) formation. The XOS production was estimated by standard chemical method (Lane and Eyon 1923). The correlation and interaction of the independent variables were determined by the Box Bohnken method (Table 2). The effect of the model was analyzed by regression coefficient, Analysis of variance (ANOVA) and response surface plots (Fig 2).

The coefficient of the factors was determined by the $\mathrm{R}^{2}$ value, this value has to be above 0.80 to good fit a model and they elucidate the accuracy of the response of the model. The regression coefficient for XOS production was significant $(\mathrm{P}<0.05)$ with an $\mathrm{R}^{2}$ value of 0.925 that determines the $92.5 \%$ accuracy. The results recommend the quadratic equation for XOS recovery from Sugarcane bagasse xylan as follow:

$$
\begin{aligned}
\mathrm{XOS}=0.6244- & 0.0143 \mathrm{~A}-0.00206 \mathrm{~B}-0.1766 \mathrm{C}-0.0264 \mathrm{D}-0.0295 \mathrm{AB}+0.0050 \mathrm{AC}+0.0493 \mathrm{BC} \\
& +0.0328 \mathrm{BD}+0.0088 \mathrm{CD}-0.0059 \mathrm{~A}^{2}-0.0071 \mathrm{~B}^{2}+0.2073 \mathrm{C}^{2}+0.0000 \mathrm{D}^{2}
\end{aligned}
$$

Where A- pH, B- Temperature, C- Enzyme, D- Time

281 Analysis of variance for the current model is significant with $\mathrm{p}<0.001$ and the lack of fit Not significant (0.4087) as the designed model perfectly fits the yield of the XOS. The maximum yield was observed in the following runs $12,19,20,26$ and 29 with $1.57 \pm 0.29,0.99 \pm 0.24,0.95 \pm 0.21,0.98 \pm 0.31$ and $1.04 \pm 0.33$ respectively. 

against two variables by keeping the other two variables at their central level. The central level for the independent variables is $\mathrm{pH}(4.75)$, temperature $\left(45^{\circ} \mathrm{C}\right)$, enzyme $(4 \mathrm{U} / \mathrm{ml})$ and time $(16 \mathrm{~h})$. When the $\mathrm{pH}$ and temperature are decreased to $\left(40\right.$ to $\left.4^{\circ} \mathrm{C}\right)$ the XOS yield was a maximum of $0.634 \mathrm{mg} / \mathrm{ml}$ (Figure $2 \mathrm{~A}$ ). The low $\mathrm{pH}(4)$ and enzyme concentration $(4 \mathrm{U} / \mathrm{ml})$ enhances the XOS yield $1.013 \mathrm{mg} / \mathrm{ml}$ and the yield declines when the enzyme concentration has increased (Figure 2B). The interaction between $\mathrm{pH}$ and Time doesn't have much impact on the production of XOS (Figure 2C). The XOS yield was gradually decreased when the temperature is decreased and the enzyme concentration increased (Figure 2D). When the time and enzyme concentration increased, the XOS yield has been reduced (Figure 2E). Interaction between the temperature and time has shown less impact in enhancing the XOS production. Hence the ideal condition concluded for the maximum yield of $\mathrm{XOS}$ is $\mathrm{pH} 4.75$, temperature $45^{\circ} \mathrm{C}$, enzyme $4 \mathrm{U} / \mathrm{ml}$ and Time $16 \mathrm{~h}$. Jayapal et al. (2013) have produced XOS at $\mathrm{pH} 4$, using enzyme at $2.65 \mathrm{U} / \mathrm{ml}$, time 8 hours and temperature $40^{\circ} \mathrm{C}$ whereas Samanta et al. (2014) produced XOS at $\mathrm{pH} 3.53$, Temperature $51.46^{\circ} \mathrm{C}$, enzyme $24.7 \mathrm{U} / \mathrm{ml}$ and time 12 hours.

\subsection{Characterization of Xylan and XOS}

298

299

300

301

302

303

304

305

306

307

308

309

310

311

312

313

314

315

316

317

318

319

\subsubsection{Fourier Transform Infra Red (FTIR) analysis of xylan and XOS}

FTIR was employed to study the functional groups present in the Xylan and XOS which corresponds to a signature molecule (Fig. 3). The FTIR spectrum for the sugarcane bagasse xylan peaks at $3762 \mathrm{~cm}^{-1}, 3347 \mathrm{~cm}^{-1}, 2917 \mathrm{~cm}^{-1}$ represents the $\mathrm{OH}$ and $\mathrm{CH}$ stretching of xylan (Peng et al. 2010, Samanta et al. 2012, Jayapal et al. 2013, and Hesam et al. 2020). The short narrow bend denotes the o acetyl group in the hemicelluloses chain, $1640 \mathrm{~cm}^{-1} \mathrm{due}^{-1}$ to the presence of residual water. $1373 \mathrm{~cm}^{-1}$ and $1219 \mathrm{~cm}^{-1}$ are due to the $\mathrm{CH}, \mathrm{OH}$, or $\mathrm{CO}$ stretching and bending vibrations of the hemicelluloses. $1033 \mathrm{~cm}^{-1}$ and $896 \mathrm{~cm}^{-1}$ denotes the1-4 $\beta$ configuration of xylan (Hasem et al. 2020). The spectrum at $1635 \mathrm{~cm}^{-1}$ represents the $\mathrm{CH}$ streaking of Xylooligosaccarides (Peng et al. 2010). Asymmetric and symmetric $(\mathrm{C}=\mathrm{O})$ stretching vibration of the Carbohydrate groups made small vibration at $3289 \mathrm{~cm}^{-1}$. A peak at $1286 \mathrm{~cm}^{-1}$ elucidates the $\mathrm{C}=\mathrm{O}$ and $\mathrm{C}-\mathrm{O}$ stretching. A small vibration at $1054 \mathrm{~cm}^{-1}$ is due to the presence of 4-O methyglucuronoxylan type oligo and polymers (Kacurakova et al. 1998).

\subsubsection{XRD analysis of xylan and XOS}

The XRD profile for xylan was represented in Fig 4. Various peaks 2 theta values ranging from 4 to 90 spectrum were observed. The narrow sharp and short broad peaks represent crystalline and amorphous phases. 9.35, 8.99, $11.14,18.72,18.90,22.6,22.34,26.64,26.65,29.7,29.36,30.82,33.88,36.42,40.89$ and 44.68 implies the interplanar spacing (d spacing) of 9.60, 7.81, 4.64, 4.12, 3.97, 3.80, 3.56, 3.33, 3.177, 3.01, 2.8, 2.75, 2.72, 2.67, $2.53,2.46$, and 2.43 . The CI index of xylan is $0.45(45 \%)$. Xylan consists of nearly equal proportions of a crystalline and amorphous phase. The 2theta values of XOS are 9.35, 18.9 and 28.4 represents the d spacing values $9.49,4.71$ and 3.13 respectively. The CI index of the XOS is 0.030 (3\%). XOS has a majorly amorphous phase with a trace of crystalline structure. Lyophilization (freeze-dried) method was adopted for processing the XOS into powder. During the process, they may let the sample absorb water leads to crystals formations in an amorphous sample (Zhang et al. 2019) 


\subsection{3 $\quad{ }^{1} \mathrm{H}$ and ${ }^{13} \mathrm{C}$ NMR spectrum characterization of XOS}

321 The protons in the xylan were analyzed by ${ }^{1} \mathrm{H}$ NMR and illustrated in Fig. 5A The main signals at 4.26 (H-1), $3223.19(\mathrm{H}-2), 3.59(\mathrm{H}-3), 3.63$ (H-4) and 3.98 (H-5) ppm imply the $\beta$ - D xylopyranosyl residues originated from 4323 o-methyl $\alpha$-D GlycpA acid $(1 \rightarrow 2)$. The protons of arabinofuranosyl determine the 5.1 to $5.4 \mathrm{ppm}$ and the minor 324 signal at 5.40ppm illustrates the Xylopyranosyl residues. The strong signal at $2.5 \mathrm{ppm}$ and $1.630 \mathrm{ppm}$ state the 325 Methylene and groups in the solvent (methanol). The ${ }^{13} \mathrm{C}$ NMR spectrum of Xylan (Fig. 5B) represents the (1$326 \rightarrow 4$ )linked $\beta$-xylan. Peaks at 102.2 (C-1), 73.04(C-2), 74.43(C-3), 75.78(C-4), 63.98 (C-5) ppm. 102.2ppm peak 327 represents the $\beta$ configuration of the backbone of the xylan confirmed by ${ }^{1} \mathrm{H}$ NMR.

328 The spectral region ranging between 4.30-5.40ppm in ${ }^{1} \mathrm{H}$ NMR confirms the presence of XOS in the sample (Fig 329 5C). The spectrum of 5.0-5.40ppm and 4.30-4.60ppm represent the $\alpha$ anomeric and $\beta$ anomeric protons. 5.32 330 ppm is the characteristic signal of $\alpha$-L-arabiofuranosyl $(\alpha$-L-Araf) residue $(1-\rightarrow 2)$ linked with the monosubstituted $331 \beta$-D xylopyranose residue. The signals at $5.07 \mathrm{ppm}$ and $4.50 \mathrm{ppm}$ illustrate the reducing end of $\mathrm{X} \alpha$ and $\mathrm{X} \beta$. $3325.20 \mathrm{ppm}$ was due to the attachment of 4-o-methyl glucuronic acid to xylose through $\alpha(1-\rightarrow 2)$ linkage. 4.45 $3334.35 \mathrm{ppm}$ is due to the protons in the internal and nonreducing end of xylosyl residues. The heterogeneity structure 334 of the XOS was analyzed by ${ }^{13} \mathrm{C}$ NMR. The signals at $91.67 \mathrm{ppm}$ and $96.54 \mathrm{ppm}$ determine the reducing end of $\alpha$ 335 and $\beta \mathrm{C}-1$. The major four signals at 72.74 (C-2), 73.48 (C-3), 76.39 (C-4), 63.05 (C-5) represent the nonreducing 336 end of the $\beta$ D xyl residues (Fig 5D). 80.76, 77.47, 84.82, 62.8ppm represents the C-2, C-3, C-4, C-5 of $\alpha \mathrm{L}-$ Ara 337 units. The signals at 101.4 and $101.7 \mathrm{ppm}$ represent the internal and non-reducing terminals confirmed by ${ }^{1} \mathrm{H}$ 338 NMR.

\section{$339 \quad$ 3.4.4 LC-MS/MS Analysis of XOS}

340 LC-MS/MS data elucidate the structure, molecular weight and distributions of acetyl groups in the XOS (Fig 6 341 and Table 3). The sharp narrow peak at $305 \mathrm{~m} / \mathrm{z}$ and $317 \mathrm{~m} / \mathrm{z}$ indicates the presence of disaccharide(xylobiose$342 \quad \mathrm{C}_{10} \mathrm{H}_{18} \mathrm{O}_{9}$ ) of two pentoses with $\mathrm{Na}^{+}$ions respectively. The peak at $361 \mathrm{~m} / z$ indicates the two pentoses with acetyl 343 and $\mathrm{Na}^{+}$ions presence. The spectrum at $462 \mathrm{~m} / z$ indicates the trisaccharide-xylotriose $\left(\mathrm{C}_{15} \mathrm{H}_{26} \mathrm{O}_{13}\right)$ with 3 pentose 344 units with $\mathrm{Na}^{+}$ions. $615 \mathrm{~m} / z$ peak represents the tetrasaccharides -xylotetrose $\left(\mathrm{C}_{20} \mathrm{H}_{34} \mathrm{O}_{17}\right)$ made up of four pentose 345 units with $\mathrm{Na}^{+}$ions and $672 \mathrm{~m} / z$ represents the presence of four pentose units with two acetyl groups in the XOS 346 (Xiao et al. 2018).

\section{$347 \quad 3.4 .5 \quad$ TGA analsyis of XOS}

348 In the TGA profile of XOS, the gradient temperature increase elucidates the difference in sample weight due to 349 the presence of volatile groups. For XOS, a weight loss of $17.11 \%$ was observed between $100^{\circ} \mathrm{C}-300^{\circ} \mathrm{C}$ due to 350 the evaporation of water vapors in the sample. After this, the sample may undergo a pyrolysis process where the sample is partially decomposed into ash and the sample loses its weight of $17.90 \%$ between $300^{\circ} \mathrm{C}-400^{\circ} \mathrm{C}$ and the sample would have completely decomposed $(14.04 \%)$ between $500^{\circ} \mathrm{C}$ to $600^{\circ} \mathrm{C}$ into ash by the combustion process (Fig 7). Differential Thermogravimetric analysis (DTG) represents the maximum degradation $\left(\mathrm{T}_{\mathrm{d}}\right.$ ) at a temperature that determines the stability of the sample. The maximum degradation of the sample was observed at 


\section{$357 \quad$ 3.5.1 Acid Indigestability}

358 The development of prebiotics has focused on the non-digestibility of oligosaccharides (Wang 2009) and to ensure 359 them to reach the colon to benefits the diversity of niche and probiotic microorganisms residing there (Gibson et 360 al. 2004). Prebiotics extracted from sugarcane bagasse were hydrolyzed with artificial gastric juice, the degree of 361 hydrolysis decreased when the $\mathrm{pH}$ of the juice increases. Hydrolysis percentage of prebiotics was compared with 362 reference prebiotic (inulin). The hydrolysis of prebiotics ranges from 5.3\%, 3.9\%, 3.89\%, 2.43\%, 2\%, 1.4\% in 363 varied $\mathrm{pH}(1-6)$ whereas, the hydrolyzed percentage of Inulin is $52 \%, 34 \%, 21.5 \%, 18 \%$ and $15.3 \%$. Maximum

364 hydrolysis (5.3\%) was observed in $\mathrm{pH} 1$ at 6 hours of incubation in gastric juice. Hence when comparing with the 365 reference prebiotic, XOS is less digested and the percentage of prebiotic reaching to the intestine is $95 \%$ 366 unhydrolyzed and the results are shown in Fig. 8. The degree of hydrolysis at $\mathrm{pH}$ 1, 2, 3 and 5 was 4.08\%, 2.3\%, $367 \quad 1.66 \%, 0.85 \%$ and $0.02 \%$ in oligosaccharides extracted from Pitaya fruits (Wichenchot et al. 2010).

\subsubsection{Prebiotic efficiency on Probiotics}

369 The efficacy of prebiotic is determined by the selective stimulation of probiotic growth and their metabolism when 370 other commensal microorganisms are available in the intestinal region The growth of all probiotic organisms has 371 increased when the incubation time increases (Fig. 9). In 24 hours L.plantarum, L.fermentum and 372 B.amyloliquefaciens are showed maximum XOS utilization in optical density of 0.99, 0.97, 0.89. Madhukumar 373 and Muralikrishna 2012, evaluated the optical density $\left(\mathrm{A}_{600 \mathrm{~mm}}\right.$ ) growth 0.296 and 0.604 of L.plantarum NDRI 374 strain 184 in Bengal gram husk and wheat bran XOS at $24 \mathrm{~h}$ incubation. Yu et al. 2015 have also reported that the 375 corncob utilization by L. plantarum QH251 and SC52 was 0.62 and 0.62 at $600 \mathrm{~nm}$.

\section{$376 \quad$ 3.5.3 Prebiotic Index and Score}

377 The prebiotic index is the measurement of growth comparison of probiotic bacteria utilizing the prebiotics and 378 the MRS medium containing glucose as the carbon source in 24 hours of incubation (Table 3A). The value below 379 and near to one is determined as the low efficiency of prebiotic on probiotic utilization. The maximum prebiotic 380 index was noted in L.plantarum (1.92), L.fermentum (1.37) and B.amyloliquefaciens (1.61) and the minimum was 381 observed in B.clausii (0.21). Huebner et al. (2007) derived a prebiotic activity score based on the cell density 382 values of probiotics on prebiotic.

383 The prebiotic score can be calculated by comparing the growth difference between probiotic bacteria in media 384 with glucose and substituted with prebiotics and Reference bacteria (E.coli) in media with glucose and prebiotic 385 substituted media (Table 3B). The score below or near one elucidates that E.coli dominates the growth of probiotic 386 bacteria. The score above one implies that the probiotic bacteria has suppressed the growth of other commensals 387 bacteria with prebiotic as carbon source. L.plantarum and L.fermentum have highest prebiotic score of 12 and 17 388 whereas least was observed in B.clausii (0.9) and E.faecium (0.57)

\section{$389 \quad 3.6 \quad$ Bacteriocin produced by probiotics on utilizing the XOS as a carbon source}

390 Bacteriocin produced by the probiotic organisms on growing in MRS media (Table 4A. Media substituted with 391 XOS (Table 4B and Fig. 10) as a carbon source were tested against the pathogens. Comparatively, the bacteriocin 392 produced on utilization of prebiotic has the high ability to inhibit the pathogen. Maximum growth inhibition was 
394 plantarum against E.fecalis $(11 \mathrm{~mm})$ and L. monocytogenes $(12 \mathrm{~mm})$. Bacillus clausii have shown growth 395 inhibition against L.monocytogenes $(12 \mathrm{~mm})$. All probiotic bacteriocins produced, have shown inhibition against

396 E.coli. Yu et al. (2015) have reported that bacteriocin from Lactobacillus plantarum S2 shown antibacterial 397 activity against Shigella flexneri and E.coli moderately (3-6mm in diameter). Least growth inhibition (0-3mm in 398 diameter) against Salmonella typhimurium and Staphylococcus aureus in all the triplicates.

\section{Conclusion}

400

Xylooligosaccharides can be produced in a single step method by autohydrolysis. But we adopted alkali extraction and enzymatic hydrolysis of xylan that is advantageous as it does not leave any toxic traces in the environment, minimal production of xylose (undesirable component) and cheap method (not laborious). Upon comparing various alkali, $\mathrm{NaOH}$ has a greater effect on xylan extraction from sugarcane bagasse. Bio process variables such as temperature, $\mathrm{pH}$, enzyme concentration and reaction time have been optimized for XOS production using RSM. As it is known that XOS is an emerging prebiotic component these days, utilization of agricultural wastes as a source for its production shall open new insights for zero waste technology that can improve gut health with proliferation of residential and probiotic flora. Production of XOS from agricultural residues shall improve socio economic status globally by converting the trash into cash.

\section{Declarations}

410 Ethics approval and consent to participate: Not applicable

411 Consent for publication: All the authors have read the manuscript and approved for its submission

412 Availability of data and materials: All the datasets are included in the manuscript

413 Competing interests: The authors declare that they have no competing interests

414 Funding: This research received no specific grants from any funding agency

415 Author's Contributions

416 NK has conceptualized and designed the experiments. NK, LG and AN carried out the experiment. VK have 417 helped in analyzing the data. Wrote the manuscript with support from KT and DRA. DRA have supervised the 418 whole experiment.

419 Acknowledgements

420 Authors are thankful to the Department of Biology, The Gandhigram Rural institute-Deemed to be University, 421 Dindigul and Deparmtent of Microbiology, Alagappa University, Karaikudi for providing the necessary laboratory 422 facilities to carry out the experiments. 
426 Figure 1 Compositional analysis of Sugarcane bagasse

427 Figure2 Optimization of external factors for the enzymatic production of Xylooligosaccharides using Response 428 Surface Methodology

429 Figure 3 FTIR characterization for alkali extracted xylan and enzymatically produced Xylooliogsaccharide

430 Figure 4 XRD pattern of alkali extracted xylan and enzymatically cleaved Xylooligosaccharide products

431 Figure $5{ }^{1} \mathrm{H}$ and ${ }^{13} \mathrm{C}$ NMR spectra for alkali extracted xylan (A, B) and its enzymatically cleaved 432 Xylooligosaccharides (C, D)

433 Figure 6 ESI-MS/MS characterization of enzymatically produced Xylooliogsaccharides

$434 \quad$ Figure 7 TGA characterization of enzymatically produced Xylooliogsaccharides

435 Figure 8 Acid Indigestability of XOS

436 Figure 9 Prebiotic efficacy of XOS produced from sugarcane bagasse and Inulin (Commercial prebiotic)

437 Figure 10 Bacteriocin activity from probiotic bacteria grown in prebiotic substituted medium against human 438 pathogens

439

440

441

442

443

444

445

446

447

448

449

450

451

452

453

454 
456 Agrupis SC, Shirley C, Maekawa E (1999) Industrail utilization of tobacco stalks (I) preliminary evaluation for 457 biomass resources. 53(1): 29-32. https://doi.org/10.1515/HF.1999.005.

458 Akpinar O, Erdogan K, Bostanci, S (2009) Enzymatic production of xylooligosaccharide from selected 459 agricultural wastes. Food and Bioproducts Processing. 87: 145-151.

460 Ayeni AO, Adeeyo OA, Oresegun, Oyinlola M, Oladimeji, Temitayo E (2015) Compositional Analysis of 461 Lignocellulosic Materials: Evaluation of an Economically Viable Method Suitable for Woody and Non-woody 462 Biomass. American Journal of Engineering Research (AJER), 4 (4): 14-19. ISSN e-ISSN: 2320-0847 p-ISSN : $4632320-0936$.

464 Bian J, Peng F, Peng P, Xu F, Sun RC (2010) Isolation and fractionation of hemicelluloses by graded ethanol 465 precipitation from Caragana korshinskii. Carbohydrate research. 345: 802-809.

Bon EP, Ferrara MA (2007) Bioethanol production via enzymatic hydrolysis of cellulosic biomass. In FAO 467 Seminar on The Role of Agricultural Biotechnologies for Production of Bioenergy in Developing Countries, 468 Rome.

469 Cardona CA, Quintero JA, Paz IC (2010) Production of bioethanol from sugarcane bagasse: status and 470 perspectives. Bioresource technology. 101: 4754-4766.

471 Carvalho DM, MartínezAbad A, Evtuguin DV, Colodette JL, Lindström ME, Vilaplana F, Sevastyanova O (2017) 472 Isolation and characterization of acetylated glucuronoarabinoxylan from sugarcane bagasse and 473 straw. Carbohydrate polymers. 156: 223-234.

474 Cerqueira DA, Rodrigues, Filho G, Silva MC (2007) Optimization of sugarcane bagasse cellulose 475 acetylation. Carbohydrate Polymers. 69: 579-582.

476 Chaikumpollert O, Methacanon P, Suchiva K (2004) Structural elucidation of hemicelluloses from Vetiver 477 grass. Carbohydrate Polymers. 57: 191-196.

478 Chandrasekharaiah M, Thulasi A, Sampath KT, Prasad CS, Samanta AK, Kolte AP (2007) Prebiotics: the rumen 479 modulator for enhancing the productivity of dairy animals. Indian Dairyman 59(8): 58-61.

480 Chapla D, Pandit P, Shah A (2012) Production of xylooligosaccharaides from corncob xylan by fungal xylanase 481 and their utilization by probiotics. Bioresour. Techol., 115: 215-221.

482 Collins MD, Gibson GR (1999) Probiotics, prebiotics, and synbiotics: approaches for modulating the microbial 483 ecology of the gut. The American journal of clinical nutrition. 69: 1052-1057.

484 Gibson GR, Probert HM, Van Loo J, Rastall RA, Roberfroid MB (2004) Dietary modulation of the human colonic 485 microbiota: updating the concept of prebiotics. Nutrition research reviews. 17: 259-275. 
486 Gibson GR, Roberfroid MB (1995) Dietary modulation of the human colonic microbiota: introducing the concept

487 of prebiotics. The Journal of nutrition. 125(6): 1401-1412.

488 Hesam F, Tarzi BG, Honarvar M, Jahadi M (2021) Pistachio (Pistacia vera) shell as a new candidate for enzymatic 489 production of xylooligosaccharides. Journal of Food Measurement and Characterization. 15: 33-45.

490 Huebner J, Wehling RL, Hutkins RW (2007) Functional activity of commercial prebiotics. International Dairy 491 Journal. 17: 770-775.

492 Jayapal N, Samanta AK, Kolte AP, Senani S, Sridhar M, Suresh KP, Sampath KT (2013) Value addition to 493 sugarcane bagasse: xylan extraction and its process optimization for xylooligosaccharides production. Industrial 494 Crops and Products 42: 14-24.

495 Jnawali P, Kumar V, Tanwar B, Hirdyani H, Gupta P (2018) Enzymatic production of xylooligosaccharides from 496 brown coconut husk treated with sodium hydroxide. Waste and Biomass Valorization, 10: 1757-1766.

497 Kačuráková M, Belton PS, Wilson RH, Hirsch J, Ebringerová A (1998) Hydration properties of xylan-type 498 structures: an FTIR study of xylooligosaccharides. Journal of the Science of Food and Agriculture. 77(1): 38-44.

499 Klaenhammer TR, Kullen MJ (1999) Selection and design of probiotics. International journal of food 500 microbiology. 50: 45-57.

501 Lane JH, Eynon L (1923) Methods for Determination of Reducing and Non-Reducing Sugars. Journal of Sciences. 502 42: 32-37.

503 Lavarack BP, Griffin GJ, Rodman D (2000) Measured kinetics of the acid-catalysed hydrolysis of sugar cane 504 bagasse to produce xylose Catalysis Today. 63: 257-265.

505 Lavarack BP, Griffin GJ, Rodman D (2002) The acid hydrolysis of sugarcane bagasse hemicellulose to produce 506 xylose, arabinose, glucose and other products. Biomass and bioenergy. 23: 367-380.

507 Madhukumar MS, Muralikrishna G (2012) Fermentation of xylo-oligosaccharides obtained from wheat bran and 508 Bengal gram husk by lactic acid bacteria and bifidobacteria. Journal of food science and technology.49: 745-752.

509 Okazaki M, Fujikawa S, Matsumoto N (1990) Effect of xylooligosaccharide on the growth of 510 bifidobacteria. Bifidobacteria and Microflora. 9: 77-86.

511 Pandey A, Soccol CR, Nigam P, Soccol VT (2000). Biotechnological potential of agro-industrial residues. I: 512 sugarcane bagasse. Bioresource technology. 74: 69-80.

513 Peng F, Ren JL, Xu F, Bian J, Peng P, Sun RC (2010) Fractional study of alkali-soluble hemicelluloses obtained 514 by graded ethanol precipitation from sugar cane bagasse. Journal of agricultural and food chemistry. 58: 17685151776.

516 Roberfroid MB (1999) Dietary fiber properties and health benefits of non-digestible oligosaccharides. CRC Press $517 \quad 1^{\text {st }}$ edition. EISBN 9780429221941 
518 Rodriguez SG, Gomez RL, Garcia GM., Cruz GA (2019) Prebiotic effect of commercial saccharides on probiotic

519 bacteria isolated from commercial products Food Science and Technology. 39(3): 747-753.

520 Rycroft CE, Jones MR, Gibson GR, Rastall RA (2001) A comparative in vitro evaluation of the fermentation 521 properties of prebiotic oligosaccharides. Journal of applied microbiology. 91: 878-887.

522 Samanta AK, Jayapal N, Kelte AP, Senani S, Sridhar M, Dhali A, suresh KP, Jayaram C and Prasad CD (2014)

523 Process for enzymatic production of xylooligosaccharides from the xylan of corn cobs. I. food precessing and 524 preservation. doI: $10.1111 /$ ifpp. 12282.

525 Samanta AK, Jayapal N, Kolte AP, Senani S, Sridhar M, Dhali A, Prasad CS (2015) Process for enzymatic 526 production of xylooligosaccharides from the xylan of corn cobs. Journal of Food Processing and 527 Preservation. 39:729-736.

528 Samanta AK, Jayapal N, Kolte AP, Senani S, Sridhar M, Suresh KP, Sampath KT (2012) Enzymatic production 529 of xylooligosaccharides from alkali solubilized xylan of natural grass (Sehima nervosum). Bioresource 530 Technology. 112: 199-205.

531 Samanta AK, Senani SS, Kolte AP, Sridhar M, Jayapal N, Devi A (2010) Optimization of condition for extraction 532 of xylan from corn byproducts. In: Proceedings of International Conference on Environmental Pollution, Water 533 Conservation and Health held at Bangalore from July 29-31 141.

534 Singh RP, Shukla MK, Mishra A, Kumari P, Reddy CRK, Jha B (2011) Isolation and characterization of 535 exopolysaccharides from seaweed associated bacteria Bacillus licheniformis. Carbohydrate Polymers. 84:10195361026.

537 Supriya A. Yadav, Snehal S. Gite, Vikram B. Lanjekar, Smita S. Nilegaonkar* and Vaishali V. Agte In vitro 538 screening of indigenous plant materials for prebiotic potential. Int.J.Curr.Microbiol.App.Sci (2014) 3(11) 137539150

540 Vazquez MJ, Alonso JL, Dominguez H, Parajo JC (2000) Xylooligosaccharides: manufacture and 541 applications. Trends in Food Science \& Technology, 11: 387-393.

542 Voragen AG (1998) Technological aspects of functional food-related carbohydrates. Trends in Food Science \& 543 Technology. 9: 328-335.

544 Wang Y (2009) Prebiotics: Present and future in food science and technology. Food Research International, 42 : $5458-12$.

546 Wichienchot S, Jatupornpipat M, Rastall RA (2010) Oligosaccharides of Pitaya (dragon fruit) flesh and their 547 prebiotic properties. Food chemistry. 120: 850-857.

548 Xiao X, Wen JY, Wang YY, Bian J, Li MF, Peng F, Sun RC (2018) NMR and ESI-MS spectrometry 549 characterization of autohydrolysis xylo-oligosaccharides separated by gel permeation 550 chromatography. Carbohydrate polymers, 195: 303-310. 
Yu X, Yin J, Li L, Luan C, Zhang J, Zhao C, Li S (2015) Prebiotic potential of xylooligosaccharides derived from

552 corn cobs and their in vitro antioxidant activity when combined with Lactobacillus. Journal of microbiology and

553 biotechnology. 25: 1084-1092.

Table 1 Comparisons between different alkali treatment on the extraction of xylan from sugarcane bagasse

\begin{tabular}{ccccccc}
\hline \multirow{2}{*}{$\begin{array}{c}\text { Alkali } \\
\text { Concentration } \\
(\boldsymbol{\%})\end{array}$} & $\begin{array}{c}\text { NaOH } \\
\text { *Xylan }(\mathbf{g})\end{array}$ & $\begin{array}{c}\text { True } \\
\text { Mield } \\
(\boldsymbol{\%})\end{array}$ & $\begin{array}{c}\text { Relative } \\
\text { yield }(\boldsymbol{\%})\end{array}$ & $\begin{array}{c}\text { *Xylan(g) } \\
\text { Mean } \pm \text { SD }\end{array}$ & $\begin{array}{c}\text { True yield } \\
(\boldsymbol{\%})\end{array}$ & $\begin{array}{c}\text { Relative } \\
\text { yield }(\boldsymbol{\%})\end{array}$ \\
\hline $\mathbf{4}$ & $0.11 \pm 0.02$ & 11 & 44 & $0.04 \pm 0.00$ & 4 & 16 \\
\hline $\mathbf{8}$ & $0.12 \pm 0.01$ & 12 & 48 & $0.07 \pm 0.00$ & 8 & 31 \\
\hline $\mathbf{1 2}$ & $0.09 \pm 0.01$ & 13 & 52 & $0.13 \pm 0.00$ & 14 & 54 \\
\hline $\mathbf{1 6}$ & $0.21 \pm 0.03$ & 16 & 64 & $0.16 \pm 0.01$ & 16 & 64 \\
\hline $\mathbf{2 0}$ & $0.21 \pm 0.00$ & 22 & 86 & $0.19 \pm 0.00$ & 18 & 72 \\
\hline $\mathbf{2 4}$ & $0.19 \pm 0.00$ & 20 & 76 & $0.15 \pm 0.07$ & 20 & 78 \\
\hline $\mathbf{2 8}$ & $0.23 \pm 0.060$ & 14 & 56 & $0.16 \pm 0.01$ & 17 & 66 \\
\hline $\mathbf{3 2}$ & $0.24 \pm 0.128$ & 13 & 52 & $0.14 \pm 0.00$ & 14 & 56 \\
\hline $\mathbf{3 6}$ & $0.24 \pm 0.133$ & 13 & 52 & $0.12 \pm 0.04$ & 13 & 50 \\
\hline $\mathbf{4 0}$ & $0.24 \pm 0.045$ & 12 & 48 & $0.07 \pm 0.01$ & 7 & 28 \\
\hline
\end{tabular}

554

555

556

557

558

559

560

561

562

563

564 
Table 2 Optimization of external factors for the enzymatic production of Xylooligosaccharides using Response Surface Methodology (RSM)

Factors

Xylooligosaccharides

$(\mathbf{m g} / \mathbf{m l})$

\begin{tabular}{|c|c|c|c|c|c|}
\hline A: pH & $\begin{array}{c}\text { B:Temperature } \\
\left({ }^{\circ} \mathbf{C}\right)\end{array}$ & $\begin{array}{c}\text { C:Enzyme } \\
(\mathrm{U} / \mathrm{ml})\end{array}$ & $\begin{array}{l}\text { D: Time } \\
\text { (h) }\end{array}$ & Observed Value & Predicted Value \\
\hline 4.00 & 45 & 12 & 8 & 0.65 & 0.66 \\
\hline 4.00 & 40 & 12 & 12 & 0.662 & 0.65 \\
\hline 4.75 & 45 & 12 & 12 & 0.74 & 0.64 \\
\hline 4.75 & 45 & 4 & 24 & 0.96 & 0.98 \\
\hline 4.75 & 45 & 20 & 8 & 0.69 & 0.68 \\
\hline 4.75 & 45 & 20 & 24 & 0.63 & 0.64 \\
\hline 4.75 & 45 & 12 & 12 & 0.53 & 0.64 \\
\hline 4.75 & 40 & 12 & 8 & 0.67 & 0.69 \\
\hline 4.75 & 45 & 12 & 12 & 0.56 & 0.63 \\
\hline 4.75 & 50 & 12 & 8 & 0.58 & 0.59 \\
\hline 4.75 & 40 & 12 & 24 & 0.53 & 0.58 \\
\hline 4.75 & 40 & 4 & 12 & 1.16 & 1.11 \\
\hline 4.75 & 45 & 12 & 12 & 0.69 & 0.63 \\
\hline 5.5 & 45 & 20 & 12 & 0.63 & 0.64 \\
\hline 4.75 & 50 & 12 & 24 & 0.56 & 0.60 \\
\hline 5.50 & 45 & 12 & 8 & 0.66 & 0.63 \\
\hline 4.00 & 50 & 12 & 12 & 0.67 & 0.63 \\
\hline 4.00 & 45 & 12 & 24 & 0.66 & 0.60 \\
\hline 4.00 & 45 & 4 & 12 & 0.99 & 1.04 \\
\hline 4.75 & 50 & 4 & 12 & 0.95 & 0.93 \\
\hline 5.50 & 40 & 12 & 12 & 0.64 & 0.67 \\
\hline 5.50 & 50 & 12 & 12 & 0.53 & 0.54 \\
\hline 4.75 & 50 & 20 & 12 & 0.68 & 0.66 \\
\hline 5.50 & 45 & 12 & 24 & 0.64 & 0.58 \\
\hline 4.75 & 45 & 12 & 12 & 0.67 & 0.63 \\
\hline 5.50 & 45 & 4 & 12 & 0.98 & 1.00 \\
\hline 4.00 & 45 & 20 & 12 & 0.62 & 0.6671 \\
\hline 4.75 & 40 & 20 & 12 & 0.69 & 0.6446 \\
\hline 4.75 & 45 & 4 & 12 & 1.04 & 1.03 \\
\hline
\end{tabular}


Table 3 LC MS/MS analysis for XOS

\begin{tabular}{|c|c|c|c|c|c|}
\hline Peak No & $\begin{array}{c}\text { Compounds other } \\
\text { than } \operatorname{XOS}(\mathrm{m} / \mathrm{z})\end{array}$ & $\begin{array}{l}\text { XOS } \\
(\mathrm{m} / \mathbf{z})\end{array}$ & $\begin{array}{l}\text { No.of Pentose } \\
\text { units }\end{array}$ & $\begin{array}{c}\text { Na+adducted } \\
\text { XOS }(\mathrm{m} / \mathrm{z})\end{array}$ & $\begin{array}{c}\text { Acetyl } \\
\text { Adducted } \\
\text { XOS } \\
(\mathbf{m} / \mathbf{z})\end{array}$ \\
\hline 1 & & 294 & 2 (Xylobiose) & 305 & \\
\hline 2 & & 294 & 2(Xylobiose) & 317 & \\
\hline 3 & & 294 & 2(Xylobiose) & 305 & 361 \\
\hline 4 & 406 & - & - & - & - \\
\hline 5 & 436 & - & - & - & - \\
\hline 6 & & 441 & 3(Xylotriose) & 462 & \\
\hline 7 & 569 & - & - & - & - \\
\hline 8 & & 588 & 4(Xylotetrose) & 615 & - \\
\hline 9 & & 588 & 4(Xylotetrose) & & 672 \\
\hline 10 & 701 & - & - & - & - \\
\hline
\end{tabular}

571

572

573

574

575

576

577

Table 4A Evaluation of prebiotic index of Xylooligosaccharides

Probiotic organisms Prebiotic Index \pm SD* for XOS 579

\begin{tabular}{lcc}
\hline Lactobacillus plantarum MT228948 & $1.926829 \pm 0.24$ & 580 \\
\hline Lactobacillus fermentum MT230901 & $1.372263 \pm 0.33$ & 581 \\
\hline Bacillus amyloliquefaciens MT193292 & $1.619565 \pm 0.37$ & 582 \\
\hline Bacillus clausii MN658363 & $0.21148 \pm 0.42$ & 5 \\
\hline Enterococcus faecium MN956828 & $1.426702 \pm 0.53$ & 583 \\
\hline
\end{tabular}


Table 4B Evaluation of Prebiotic Score by comparing the growth of Probiotics and E. coli ibqhe prebiotic (XOS) substituted and synthetic medium

Prebiotic Score \pm SD* 591

Probiotic organisms

$4 \mathrm{~h} \quad 48 \mathrm{R}^{92}$

\begin{tabular}{lcr}
\hline Lactobacillus plantarum MT228948 & $12.437 \pm 0.64$ & $00.737 \pm 0059$ \\
\hline Lactobacillus fermentum MT230901 & $17.289 \pm 0.34$ & $00.979 \pm 0.52$
\end{tabular}

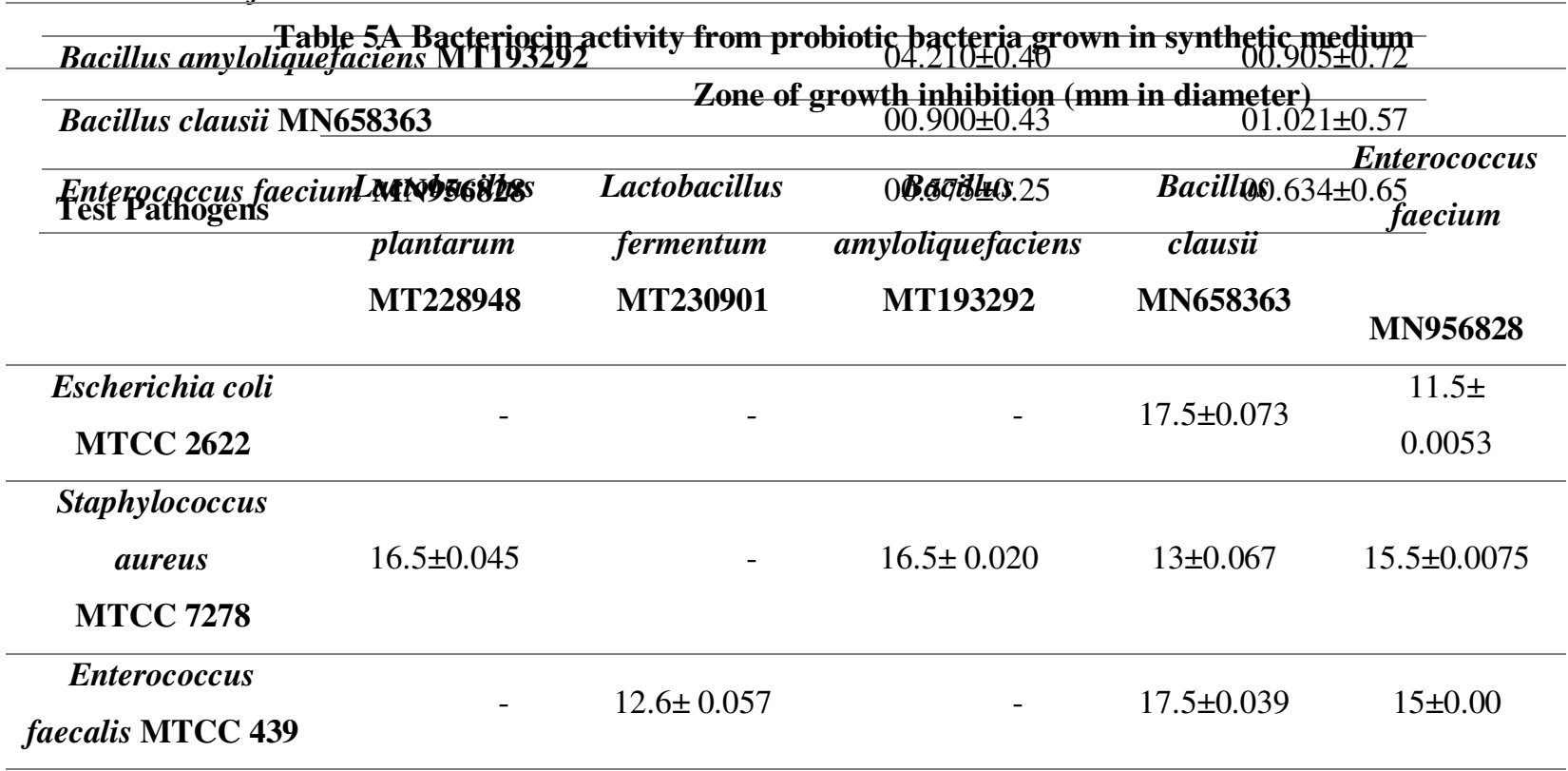

\begin{tabular}{|c|c|c|c|c|c|}
\hline $\begin{array}{c}\text { Listeria } \\
\text { monocytogenes }\end{array}$ & - & - & $18.5 \pm 0.065$ & $12.5 \pm 0.049$ & - \\
\hline МTCC 657 & & & & & \\
\hline Streptococcus & & & & & \\
\hline $\begin{array}{c}\text { pyogenes MTCC } \\
442\end{array}$ & $5.5 \pm 0.070$ & $4.9 \pm 0.820$ & - & - & $5 \pm 0.034$ \\
\hline
\end{tabular}

594

595

596

597

598 
Table 5B Bacteriocin activity from probiotic bacteria grown in prebiotic substituted medium Test Zone of growth inhibition ( $\mathrm{mm}$ in diameter)

\begin{tabular}{cccccc} 
Pathogens & Lactobacillus & Lactobacillus & Bacillus & Bacillus & Enterococcus \\
\cline { 2 - 6 } & plantarum & fermentum & amyloliquefaciens & clausii & faecium \\
& MT228948 & MT230901 & MT193292 & MN658363 & MN956828
\end{tabular}

\begin{tabular}{cccccc}
\hline Escherichia & $11 \pm 0.63$ & $11 \pm 0.57$ & $7 \pm 0.28$ & $8 \pm 0.08$ & $10 \pm 0.57$ \\
coli & & & & \\
MTCC 2622 & & & & \\
\hline
\end{tabular}

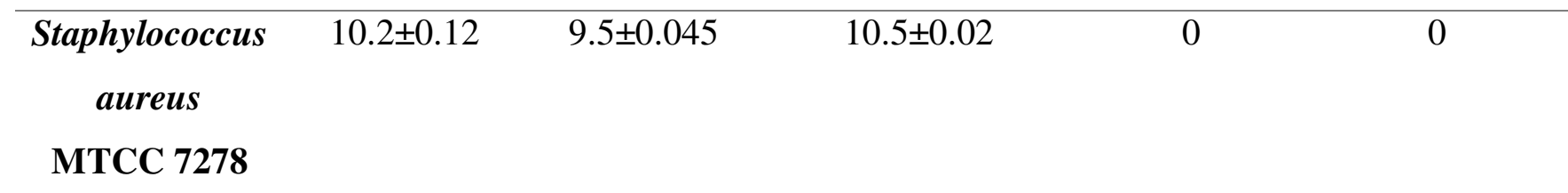

\begin{tabular}{llllll}
\hline $\begin{array}{c}\text { Enterococcus } \\
\text { faecalis }\end{array}$ & $11 \pm 0.57$ & $10 \pm 1.52$ & $12 \pm 0.52$ & 0 & $13 \pm 0.04$ \\
& & & & &
\end{tabular}

MTCC 439

\begin{tabular}{cccccc}
\hline $\begin{array}{c}\text { Listeria } \\
\text { monocytogenes } \\
\text { MTCC } 657\end{array}$ & $12 \pm 0.72$ & $11 \pm 0.57$ & 0 & $12 \pm 0.5$ & 0 \\
\hline $\begin{array}{c}\text { Streptococcus } \\
\text { pyogenes } \\
\text { MTCC } 442\end{array}$ & $6 \pm 0.22$ & - & - & $7 \pm 0.03$ & $11 \pm 0.034$ \\
& & & & \\
\hline
\end{tabular}

602

603

604

605

606

607

608 
611

612

613 
Figures

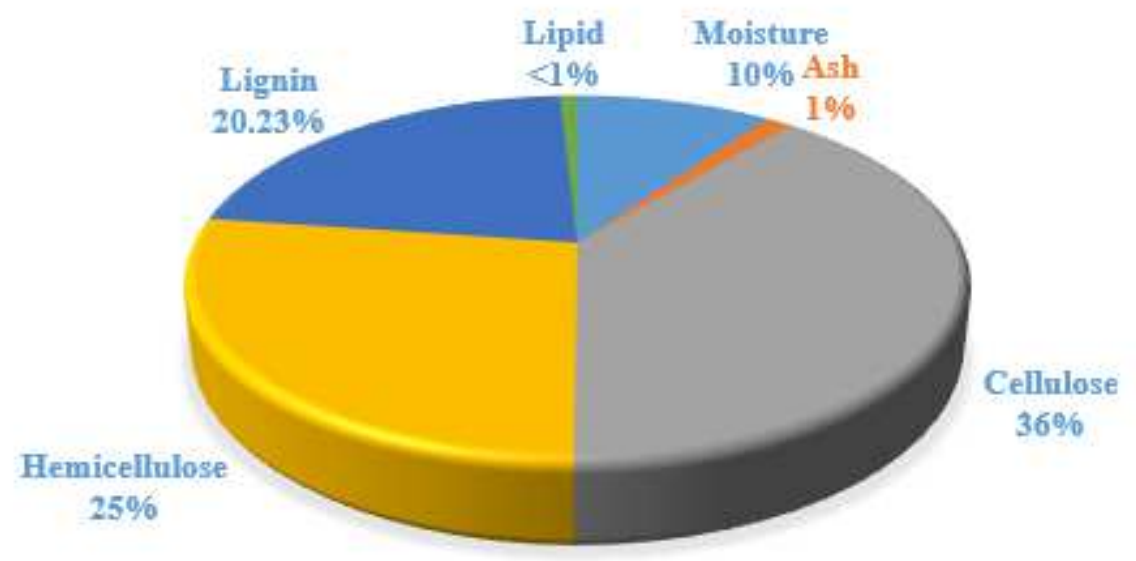

Figure 1

Compositional analysis of Sugarcane bagasse 


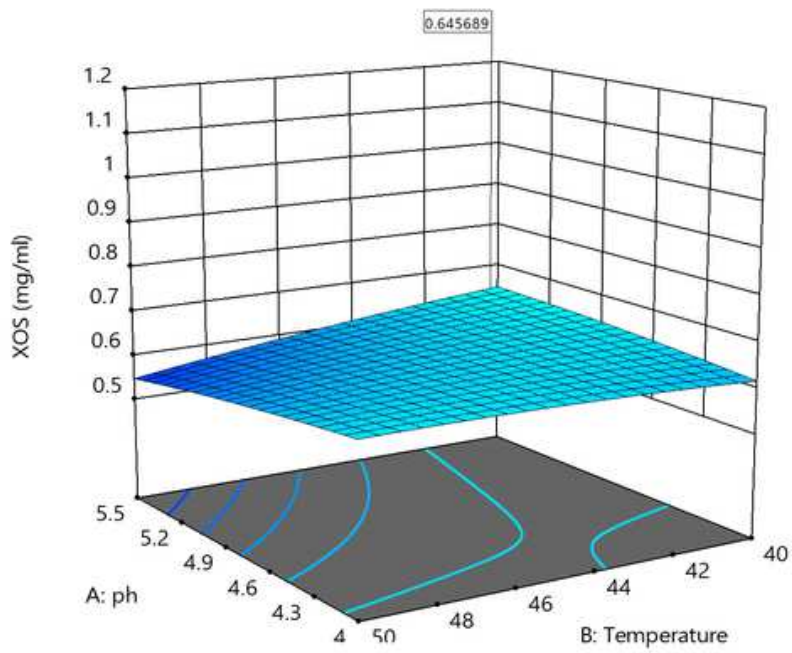

A

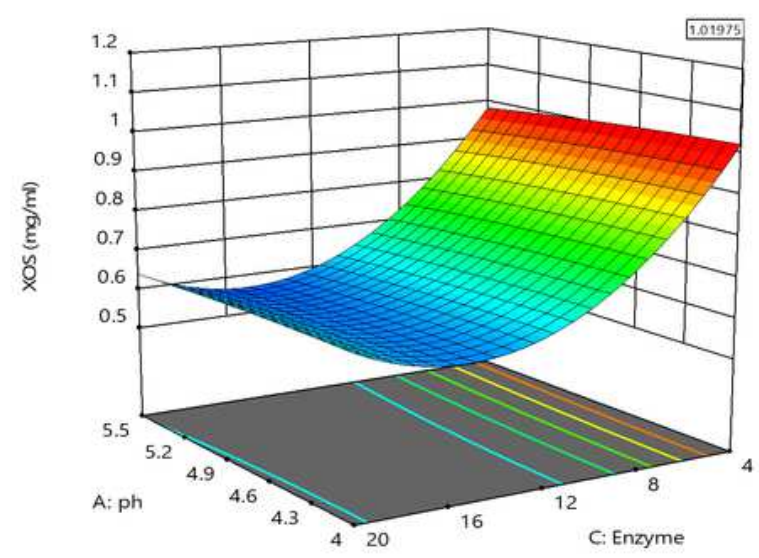

C

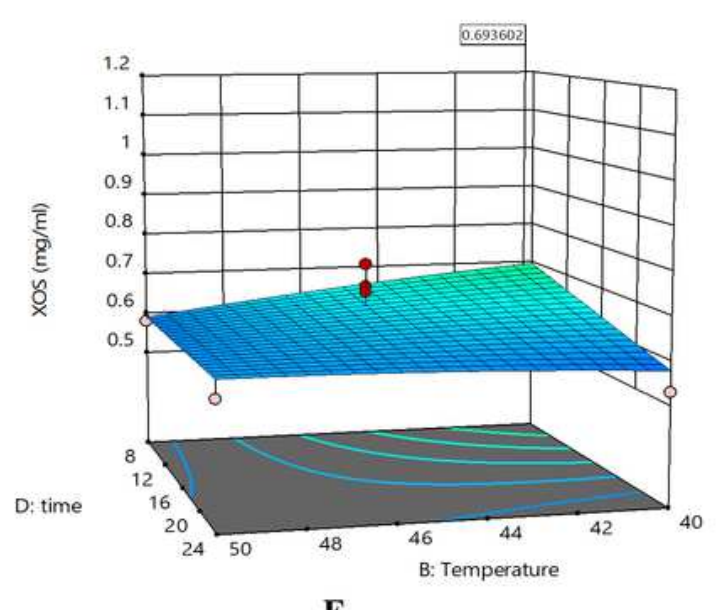

$\mathbf{E}$

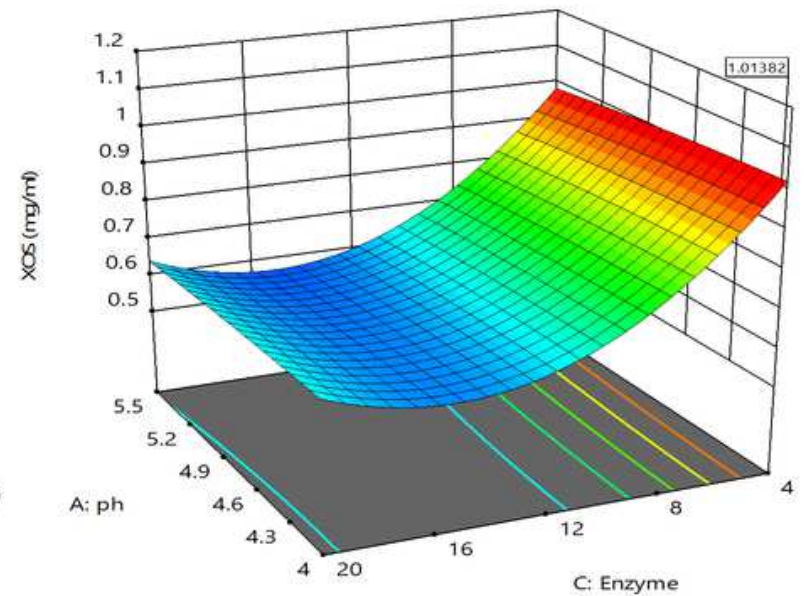

B

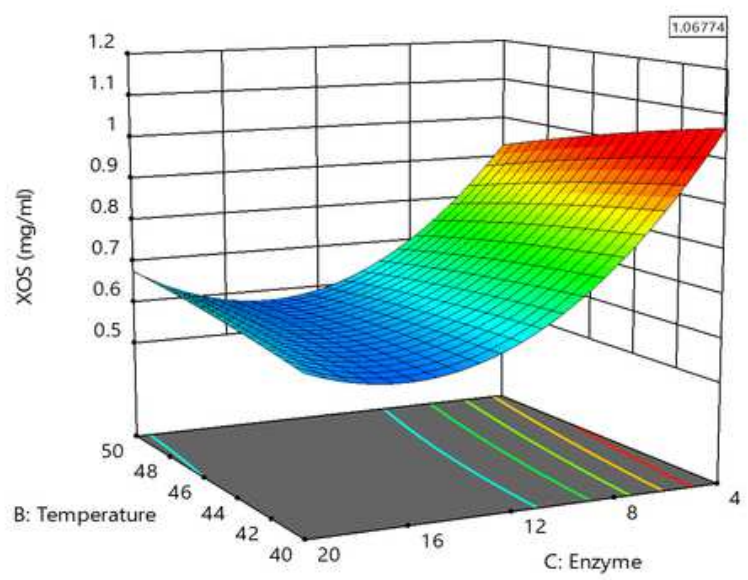

D

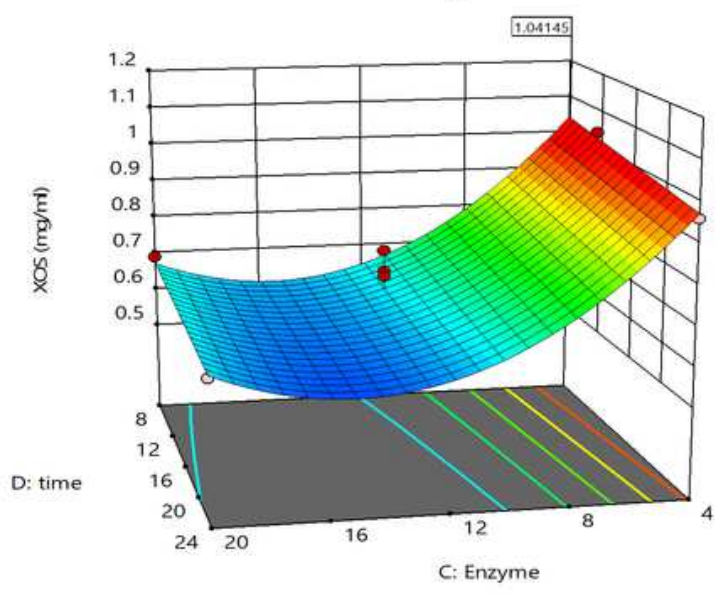

$\mathbf{F}$

\section{Figure 2}

Optimization of external factors for the enzymatic production of Xylooligosaccharides using Response Surface Methodology 


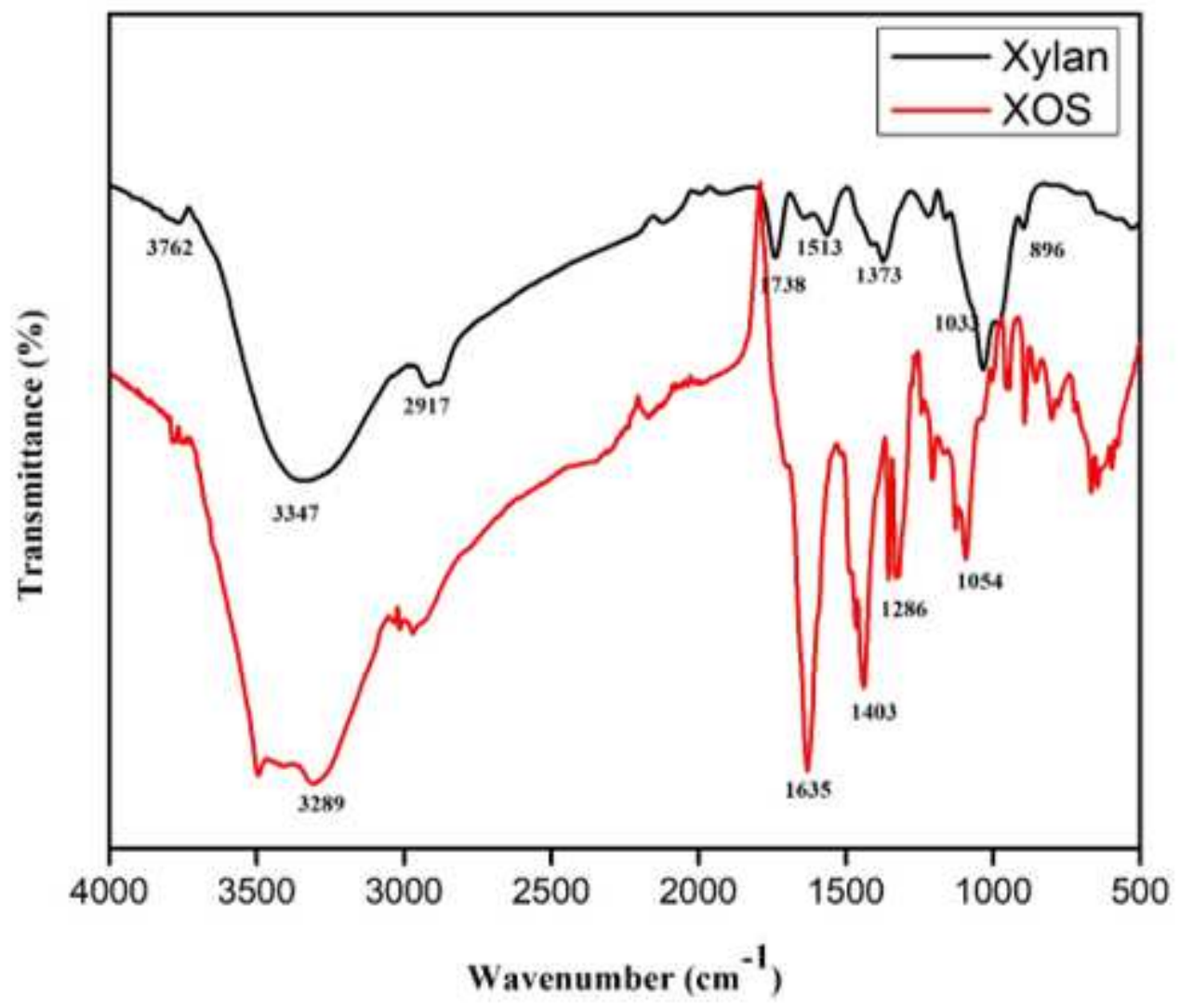

Figure 3

FTIR characterization for alkali extracted xylan and enzymatically produced Xylooliogsaccharide 


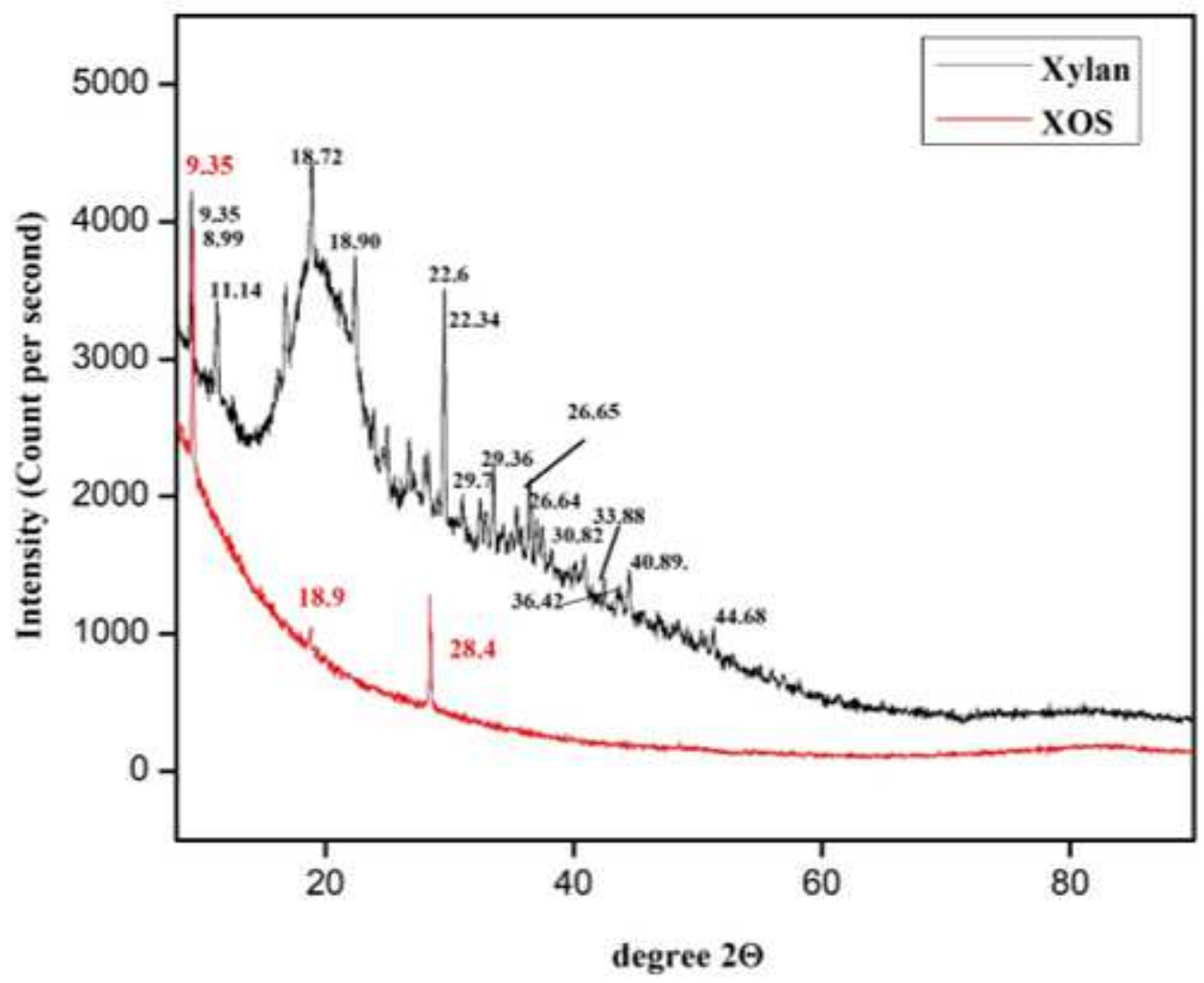

Figure 4

XRD pattern of alkali extracted xylan and enzymatically cleaved Xylooligosaccharide products 

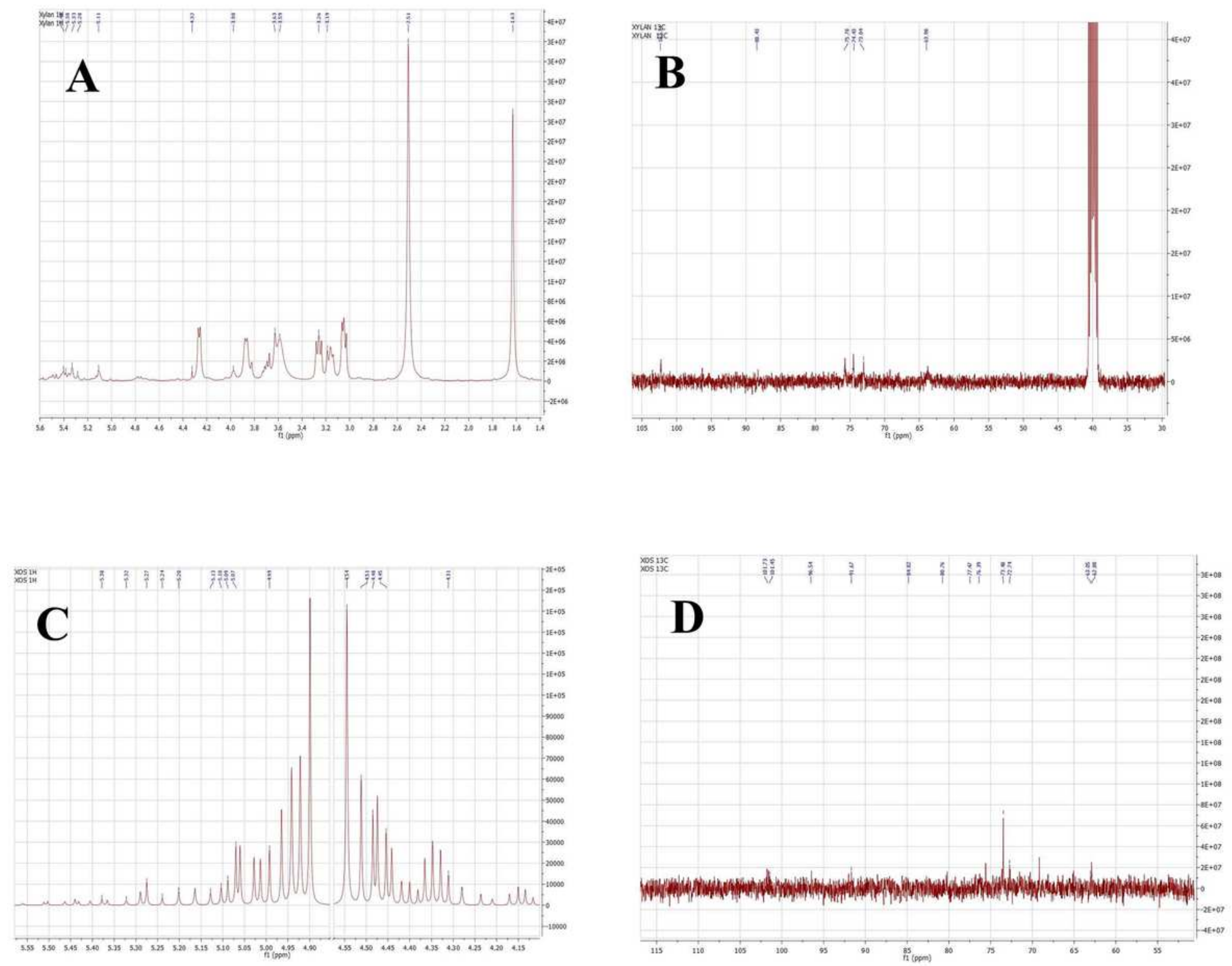
A. ${ }^{1} \mathrm{H}$ of Xylan
B. ${ }^{13} \mathrm{C}$ of Xylan
C. ${ }^{1} \mathrm{H}$ of XOS
D. ${ }^{13} \mathrm{C}$ of XOS

\section{Figure 5}

$1 \mathrm{H}$ and $13 \mathrm{C}$ NMR spectra for alkali extracted xylan (A, B) and its enzymatically cleaved Xylooligosaccharides (C, D) 


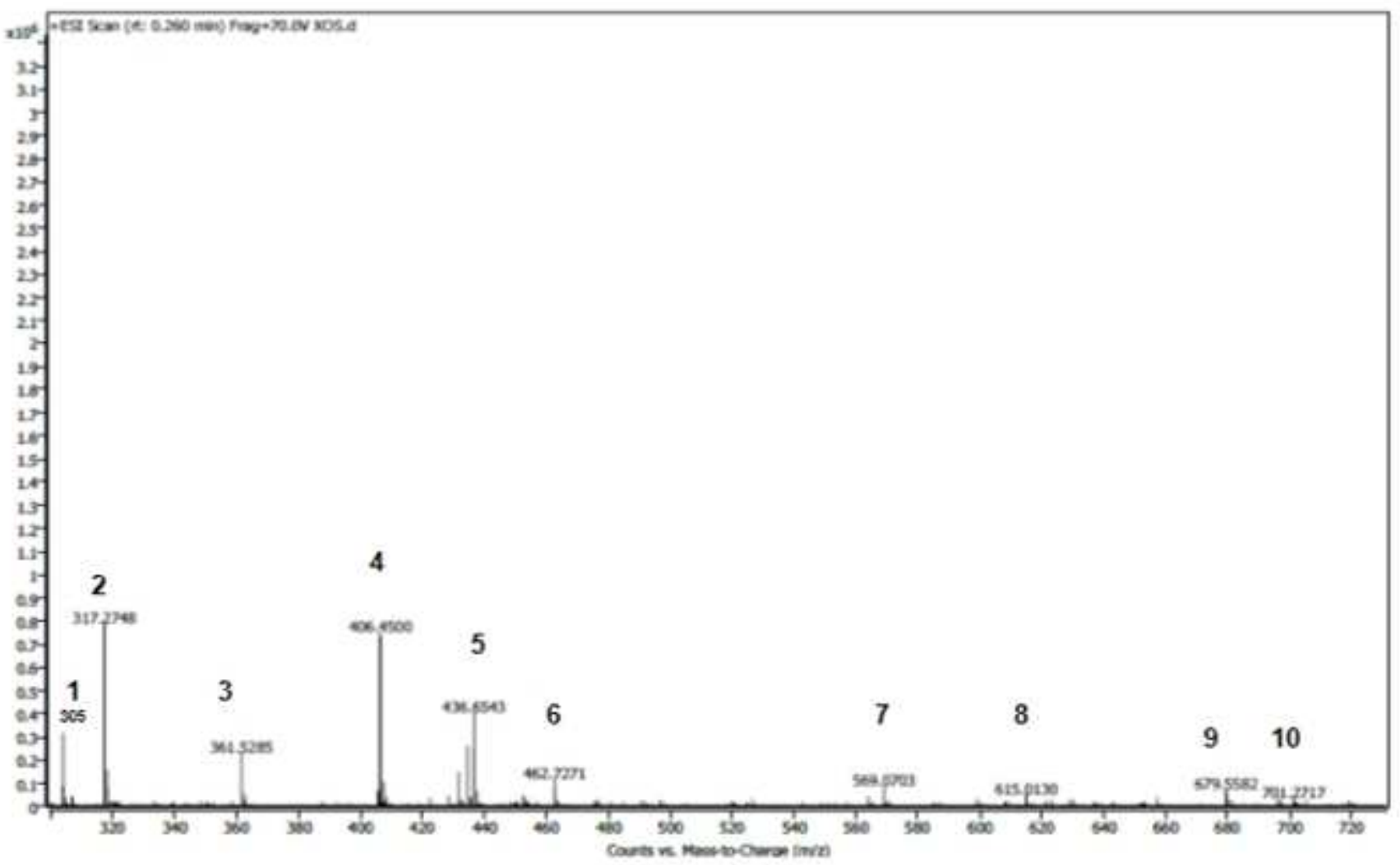

Figure 6

ESI-MS/MS characterization of enzymatically produced Xylooliogsaccharides 


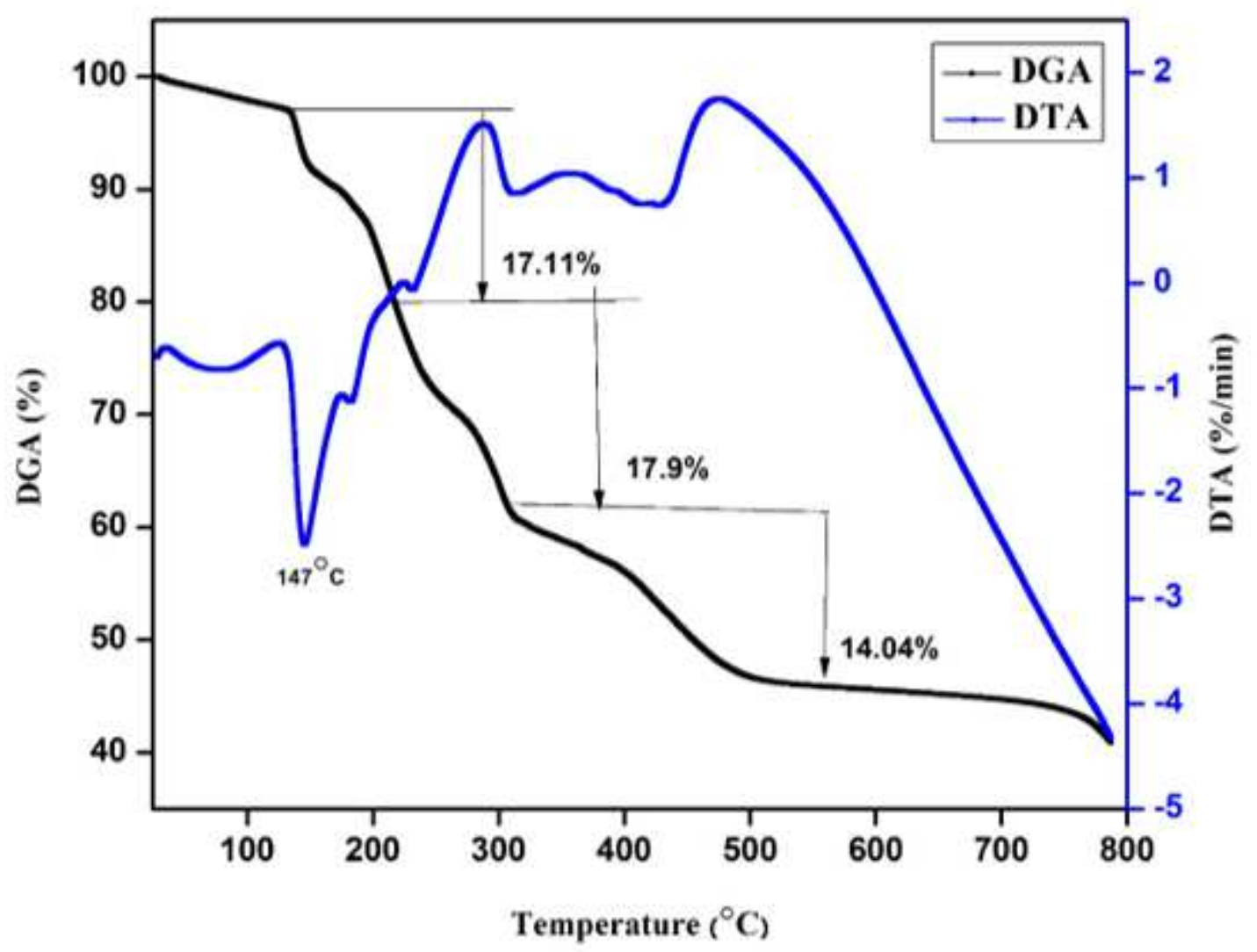

Figure 7

TGA characterization of enzymatically produced Xylooliogsaccharides 

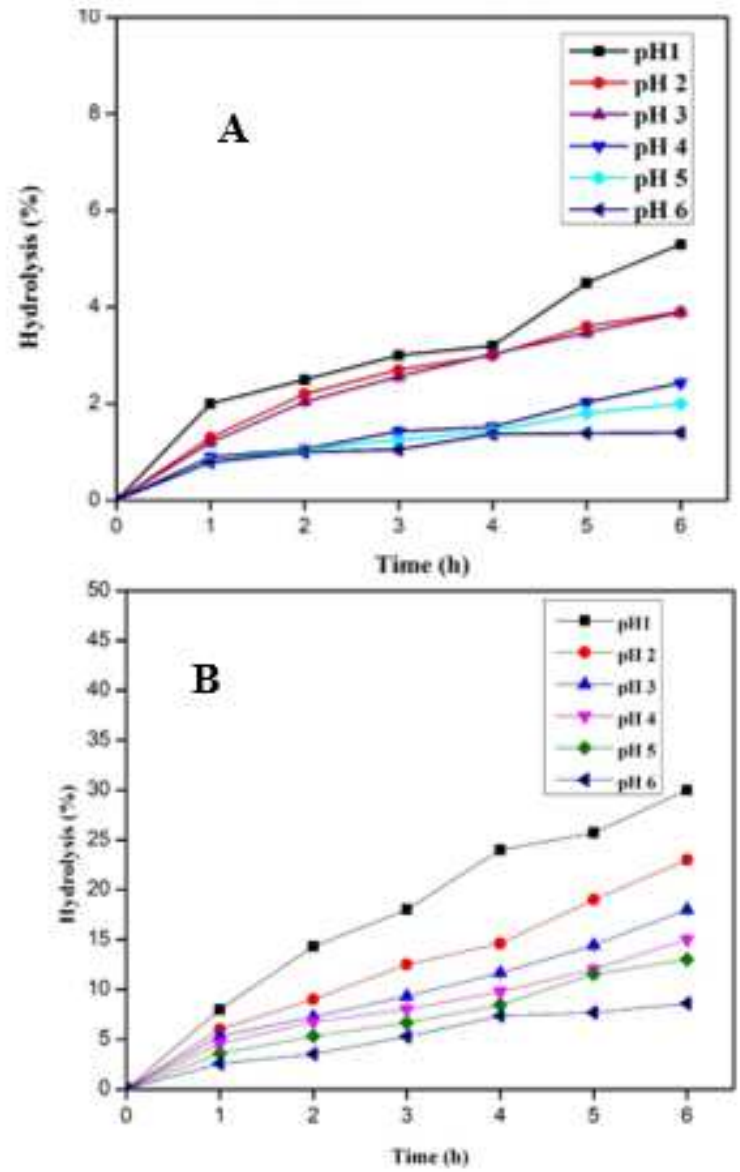

A- Acid Indigestability of XOS

B- Acid Indigestability of Inulin

Figure 8

Acid Indigestability of XOS 

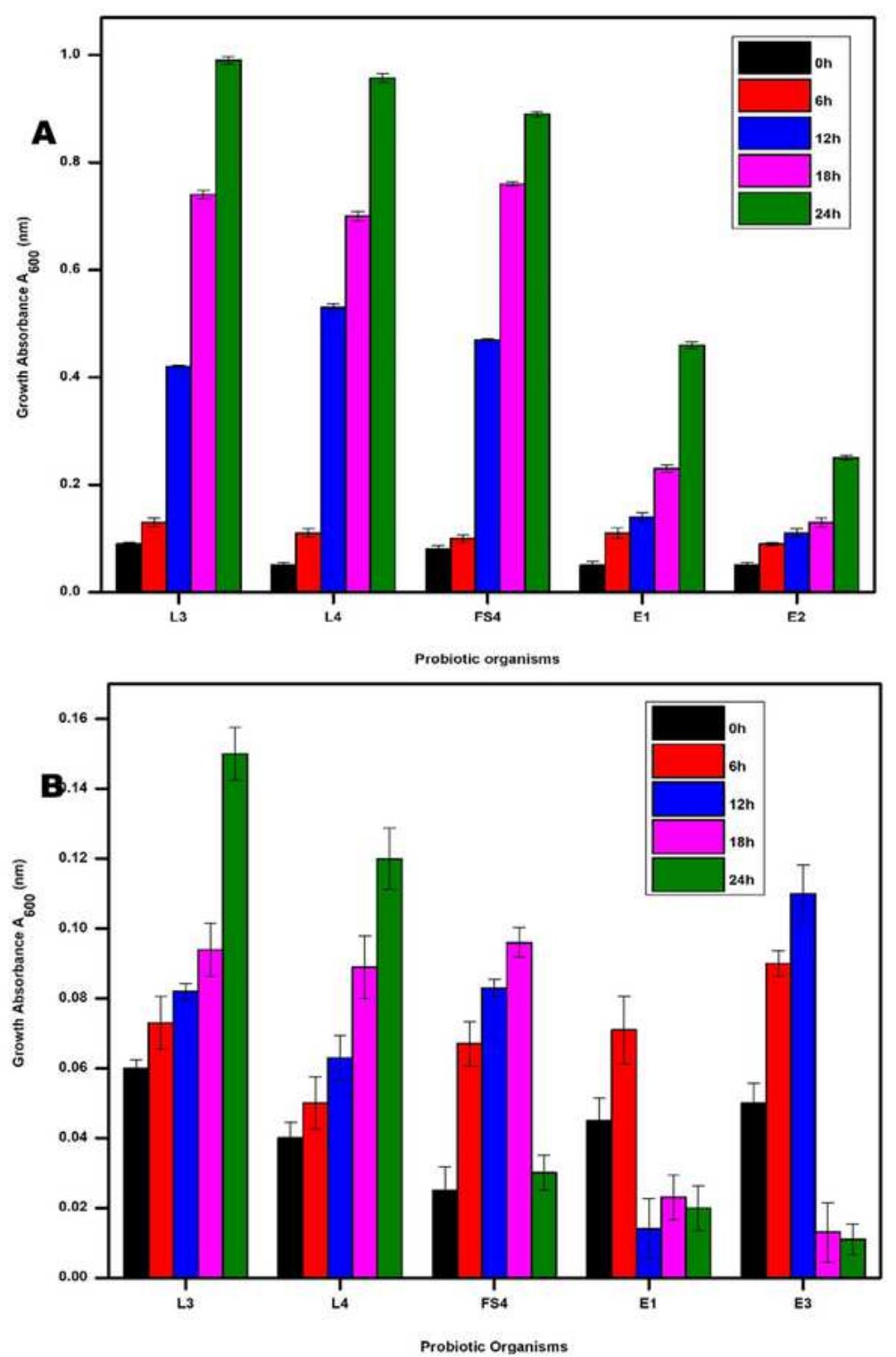

\begin{abstract}
A Prebiotic efficacy of XOS
R Prohintic afficany of Inulin

L3 Lactobacillus plantarum MT228948

L4 Lactobacillus fermentum MT230901

FS4 Bacillus amyloliquefaciens MT193292

E1 Bacillus clausii MN658363
\end{abstract}

E3 Enterococcus faecium MN956828

Figure 9

Prebiotic efficacy of XOS produced from sugarcane bagasse and Inulin (Commercial prebiotic) 

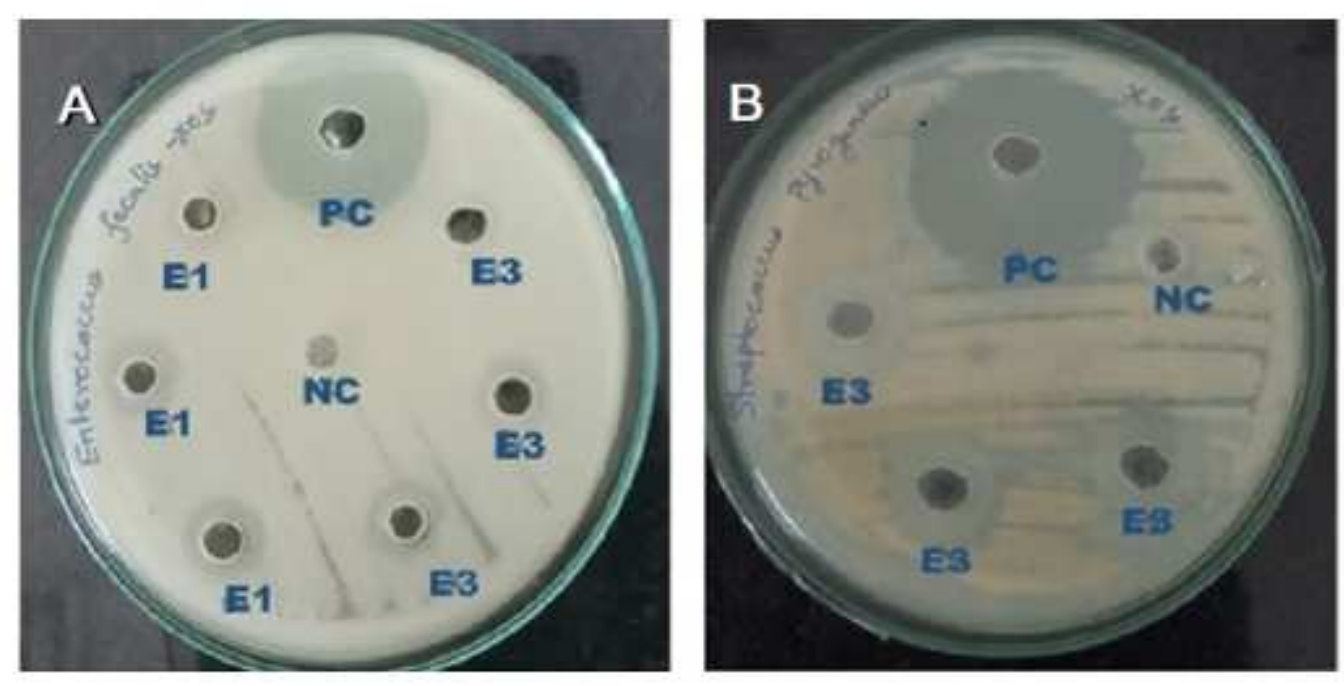

Figure 10

Bacteriocin activity from probiotic bacteria grown in prebiotic substituted medium against human pathogens. Note: A and B probiotic organisms against Enterococcus fecalis and Streptococcus pyogenes, E1 Bacillus clausii MN658363; PC Positive Control; E3 Enterococcus faecium MN956828; NC Negative Control

\section{Supplementary Files}

This is a list of supplementary files associated with this preprint. Click to download.

- Supplementary.docx 